\title{
Article \\ Evaluation of Bioactive and Physicochemical Properties of White and Black Garlic (Allium sativum L.) from Conventional and Organic Cultivation
}

\author{
Katarzyna Najman *, Anna Sadowska (D) and Ewelina Hallmann (D) \\ Department of Functional and Organic Food, Institute of Human Nutrition Sciences, \\ Warsaw University of Life Sciences, Nowoursynowska 159c, 02-776 Warsaw, Poland; \\ anna_sadowska@sggw.edu.pl (A.S.); ewelina_hallmann@sggw.edu.pl (E.H.) \\ * Correspondence: katarzyna_najman@sggw.edu.pl; Tel.: +48-22-59-370-55
}

check for updates

Citation: Najman, K.; Sadowska, A.; Hallmann, E. Evaluation of Bioactive and Physicochemical Properties of White and Black Garlic (Allium sativum L.) from Conventional and Organic Cultivation. Appl. Sci. 2021, 11, 874. https://doi.org/10.3390/ app11020874

Received: 25 December 2020

Accepted: 18 January 2021

Published: 19 January 2021

Publisher's Note: MDPI stays neutra with regard to jurisdictional claims in published maps and institutional affiliations.

Copyright: (c) 2021 by the authors. Licensee MDPI, Basel, Switzerland. This article is an open access article distributed under the terms and conditions of the Creative Commons Attribution (CC BY) license (https:/ / creativecommons.org/licenses/by/ $4.0 /)$.

\begin{abstract}
The aim of this study was to evaluate the bioactive and physicochemical properties of white and black garlic (Allium sativum L.) from conventional and organic cultivation. Both white conventional (G) and organic (EG) garlic were processed during 45 days heat treatment at $70{ }^{\circ} \mathrm{C}$ temperature and $80 \%$ relative humidity. In black garlic (BG) samples the content of soluble solids, total reducing sugars, total polyphenol as well as antioxidant activity significantly $(p<0.05)$ increased (by about $33.5 \%, 60.5 \%, 118.4 \%, 125.8 \%$, respectively), while a $\mathrm{pH}$ significantly $(p<0.05)$ decreased (by about $41.1 \%$ ) as compared to white garlic samples. The study showed significant differences between colour of white and black garlic, both in the $L^{*} a^{*} b^{*}$ and RGB colour space, especially in the case of the $L^{*}$ parameter, indicating that the colour of garlic changed from white to dark brown or black during the thermal processing. All organic garlic samples had improved bioactive ingredients and antioxidant activity compared to conventional garlic for both fresh (unprocessed) and heattreated black garlic. The production of black garlic, especially organic (EBG), allows one to obtain a product with higher amount of bioactive compounds, which can be widely used in the design of health-promoting functional food.
\end{abstract}

Keywords: black garlic; Allium; ${ }^{\circ}$ Brix; reducing sugars; polyphenols; antioxidant activity; $L^{*} a^{*} b^{*}$ colour space; organic food

\section{Introduction}

Garlic (Allium sativum L., Alliaceae) is an onion plant known since antiquity, originating from Central Asia and nowadays cultivated in many countries as a spice and medicinal plant [1]. In traditional and ancient medicine, garlic was used as a remedy for many diseases and ailments. Even today, this popular, inconspicuous plant is used not only in all cuisines of the world, but also in medicine, which has thoroughly studied the beneficial effect of garlic on the human body [2,3]. Garlic is distinguished by a very rich range of nutritional values. It contains, among others, proteins, amino acids, carbohydrates, fibre, lipids, pectins and mucous compounds [4-6]. In addition, garlic is a source of such minerals as calcium, magnesium, iron, selenium, phosphorus, chlorine, zinc and iodine. It also contains rare trace elements: nickel, cobalt, and chromium. Moreover, garlic provides many vitamins (A, PP, C, B1, B2) [6-8]. A small clove contains its most valuable bioactive substances, including polyphenolic compounds, mainly flavonoids and phenolic acids, but above all a mixture of various sulphur compounds, which determine both the versatile biological and therapeutic effect of garlic, as well as its exceptional culinary properties [3,4,9-12].

In the literature, garlic is described as a plant highly valued for its rich healthpromoting properties [4,9-14]. It has an antifungal effect and effectively helps the body in the fight against viruses or parasites [15-20]. It prevents infections and inflammatory processes and is used against colds and respiratory diseases [21-23]. It works perfectly 
as a natural antibiotic and shows strong bactericidal properties, effectively fighting infectious bacteria infecting, among others, skin, mouth, gastrointestinal, respiratory, and urinary tract [24,25]. Stimulating production of bile and accelerating intestinal peristalsis, it has a beneficial effect on the functioning of the digestive system. Fighting the bacteria Heliobacter pylori, which are the cause of indigestion and even stomach cancer, garlic has a good effect on the entire digestive tract [25-27]. Garlic also has an immunomodulatory effect by stimulating the activity of natural killer cells and macrophage phagocytosis, activating the response of lymphocytes to myogens and cytokines [28,29], as well as improves the elasticity of arteries and lowers blood pressure [30-32]. It effectively lowers cholesterol and triglycerides. Given the above, garlic can be helpful in preventing heart attacks, strokes, and other diseases of the cardiovascular system [33-35]. It is also known for its antidiabetic [36-38], anti-inflammatory, anti-rheumatic [39], and even anti-cancer properties, associated with a strong antiproliferative and proapoptotic effect on various cancer cells [40-44]. Garlic also exhibits outstanding antioxidant abilities, is a strong free radical scavenger, interrupts free radical reactions, and supports the action of endogenous antioxidative enzymes, increasing the body's ability to fight free radicals and, thus, is extremely effective in preventing many civilizational diseases [45-48].

The versatile health effects and physiological properties of garlic, widely documented in the literature, are attributed to the variety of bioactive compounds, mainly polyphenolic substances with strong antioxidant properties $[3,4,6,13,47,49-55]$. The organosulphuric compounds naturally collected in garlic include: colourless and odourless alliin (s-allyl-Lcysteine sulphoxide), $\gamma$-glutamyl-s-allyl-cysteine (GSAC), and their derivatives, formed during mechanical damage of garlic cloves. During cutting, crushing, chopping, biting, and various technological procedures (including heat treatment), under the influence of the released vacuolar enzyme (allinase), various derivatives of sulphuric compounds of alliin hydrolysed to allicin are formed, including sulphides (DAS), disulphides (DADS), diallyl trisulphides (DATS), S-allyl-cysteine (SAC), and ajoenes, which determine both the bioactive properties and sensory qualities of garlic (taste and smell) [56-61]. They give fresh garlic its typical sharp taste and aroma. Natural, baked, dried, marinated, in the form of cloves, flakes, powder, or oil, it gives the dishes a distinct and intense aroma, without which many of them would lose their specific character. Its taste and aroma make it a rather controversial spice. For some it is an indispensable ingredient, while others do not tolerate its characteristic aroma [13]. In addition to bad breath or body odour, excessive consumption of raw unprocessed garlic can cause burning in the oesophagus, nausea, vomiting, diarrhoea, indigestion, abdominal and stomach pain, and even ulceration of the stomach wall or intestines [62]. Despite a wide range of its health-promoting properties, fresh garlic consumption is declining, with the exception of China and India [63], and new methods of its processing are being sought to eliminate unpleasant odour, improve sensory properties, and even strengthen its beneficial health-promoting and therapeutic properties.

Thermal processing is widely applied in food production to obtain a greater range of colours and flavours, as well as improve the texture, digestibility, nutritional and healthpromoting value of food products [64,65]. Depending on the type (cooking, baking, frying, or microwaving), intensity and time of its use, food processing modifies the structure, composition and mutual proportions of bioactive compounds. It changes their bioavailability, thereby affecting the physiological effects of plants $[33,35,46,65,66]$.

The exact origin of black garlic is not fully known. Most sources attribute it to the cultures of the Far East, i.e., today's China, Japan and Korea, where, even now, its production is greatest. Black garlic is a product of heat treatment carried out in the range of temperature between $60{ }^{\circ} \mathrm{C}$ and $90^{\circ} \mathrm{C}$ and humidity conditions of $70-90 \%$ for a different but relatively long time (usually $60-90$ days) [60,64,67-70]. During this time, garlic acquires a new colour and loses its characteristic smell and sharp taste. Not only sensory characteristics of garlic change, but also its nutritional and health-promoting properties. By changes in, among others, the water content, the texture of garlic becomes more jelly-like, rubbery and greasy, making black garlic softer and stickier $[8,60,64,70,71]$. As a result 
of enzymatic and non-enzymatic browning, caramelization and oxidation of phenolic compounds, garlic changes colour from white to brown and eventually becomes black. It also acquires a completely different taste and aroma [72,73]. The increasing content of organic acids decrease significantly the $\mathrm{pH}$ of black garlic [64,67-69]. In addition, the content of reducing sugars (mainly fructose) produced in the hydrolysis of polysaccharides which are present in fresh garlic increases many times [70,71,74-76]. During the producing of black garlic the amount of the Maillard products increase, ultimately leading to the sweet and sour taste of raw garlic, with a hint of prunes, apricot and vanilla [8,67,77-79]. At the same time, volatile organosulphuric compounds present in fresh garlic, including allicin, responsible for the irritating, sharp taste and aroma of garlic, are converted into stable, soluble and odourless substances with strong antioxidant properties such as Sallyl-L-cysteine (SAC), sulphides (DAD), disulphides (DADS), trisulphides (DATS), diallyl (DAS), dithiines and ajoenes $[14,60,64,77]$. Polyphenolic compounds, including flavonoids and phenolic acids, are also affected, and their content repeatedly increases as compared to fresh, unprocessed garlic during the processes of long-lasting heat treatment, which leads to a several, or even many times higher, antioxidant activity of black garlic [68-70,80-83].

Production of black garlic is a process influenced by many different factors, ranging from the quality of the raw material, depending on the genotype (species, variety), environmental conditions (climate, conventional or organic cultivation system, fertilization with sulphur, harvesting conditions), through storage and pre-treatment, to the type of processing technology applied $[55,64,68,69,72,73,84]$. The literature describes the properties of black garlic depending on the time, humidity or temperature of processing, but still fails to provide sufficient data on the composition and metabolism of the bioactive compounds present in garlic during its aging. It also lacks comparative results of the amount of bioactive compounds and physicochemical properties of both organic and conventional black garlic.

Therefore, taking the above into account, this study aims to evaluate the bioactive and physicochemical properties of white (unprocessed) and black (processed) garlic (Allium sativum $\mathrm{L}$.) from two cultivation systems and to analyse the effect of long-term ( 45 days) heat treatment of garlic in high humidity of $80 \%$ and temperature $70{ }^{\circ} \mathrm{C}$ on the amount of soluble solids ( ${ }^{\circ}$ Brix), reducing sugars, polyphenolic compounds, antioxidant activity and colour parameters (in the colour space $L^{*} a^{*} b^{*}$ and RGB) of organic and conventional garlic samples. The results of this study can provide valuable guidance for organic and functional food producers, as well as consumers seeking products with high nutritional, bioactive and health-promoting values. Similar studies are crucial for determining the optimal conditions for processing garlic to obtain a product with the best technological, nutritional, dietary and functional properties of black garlic.

\section{Materials and Methods}

\subsection{Materials}

The experiment was carried out in 2020. The material for the research was garlic of the "Harnaś" cultivar from organic and conventional cultivation system. About $2.0 \mathrm{~kg}$ of fresh, both conventional and organic garlic were obtained from farms located in the Warmian-Masurian Voivodeship, Lubawa, Poland. Fresh garlic was stored in a refrigerator at $10^{\circ} \mathrm{C}$ and $85 \%$ relative air humidity for $24 \mathrm{~h}$, after that 20 conventional (total weight $1274.04 \mathrm{~g}$ ) and organic (total weight $1316.79 \mathrm{~g}$ ) bulbs of similar weight were selected for the study. The average weight of the bulbs were $63.70 \pm 1.11 \mathrm{~g}$ and $65.86 \pm 1.21 \mathrm{~g}$, respectively, for conventional and organic fresh garlic. The fresh material was divided into two parts, one for the evaluation of bioactive and physicochemical properties of fresh material (white garlic $G$ and EG) and the other for the black garlic (BG and EBG) manufacture. Black garlic was produced by thermal treatment of whole garlic bulbs in humidity chamber (HCP70, Memmert GmbH and Co. KG, Schwabach, Germany) at $70{ }^{\circ} \mathrm{C}$ temperature and with $80 \%$ relative humidity for 45 days. In the black garlic produced in this way, some physicochemical tests were performed. The rest of the research plant material, both fresh, 
white (G and EG) and black garlic (BG and EBG), were peeled, divided into cloves and frozen in liquid nitrogen and then lyophilized in a freeze dryer (Alpha 1-4 LSC, Martin Christ $\mathrm{GmbH}$, Osterode am Harz, Germany) at a chamber pressure of $10 \mathrm{~Pa}$, a drying chamber temperature of $-50^{\circ} \mathrm{C}$ and a shelf of $21^{\circ} \mathrm{C}$ for $72 \mathrm{~h}$. The freeze-dried material was ground in a laboratory knife mill (Grindomix GM 200, Retsch GmbH, Haan, Germany), packed into Falcone tubes and were stored in freezing conditions at $-20{ }^{\circ} \mathrm{C}$ until analysis. Analyses and determinations were performed on representative, homogeneous samples obtained after mixing all test material within each group, i.e., G, EG, BG, EBG.

\subsection{Methods}

\subsubsection{Dry Matter Content, $\mathrm{pH}$, Soluble Solids Content ( ${ }^{\circ}$ Brix) of Garlic Samples}

The dry matter content of the garlic samples was determined according to the AOAC method [85]. The weighing vessels were weighed, filled with garlic samples and reweighed, then placed in a drying oven (SUP 200W, Wamed, Warsaw, Poland) at $105^{\circ} \mathrm{C}$ for $72 \mathrm{~h}$. The dry matter content was calculated based on their weight differences and expressed as a percentage (\%). Garlic $\mathrm{pH}$ was measured by the potentiometric method in an aqueous solution in the weight ratio of 1:5 (garlic $(\mathrm{g})$ : water $(\mathrm{g})$ ), with a pH meter (Elmetron CP-511, Elmetron G.P., Zabrze, Poland), at room temperature $\left(20^{\circ} \mathrm{C}\right)$. Garlic soluble solids content ( ${ }^{\circ}$ Brix) were measured by Abbe Refractometer (ORT-1, Kern \& Sohn GmbH, BalingrenFrommern, Germany) at room temperature $\left(20^{\circ} \mathrm{C}\right)$. Dry matter content, $\mathrm{pH}$ and soluble solids content $\left({ }^{\circ}\right.$ Brix) were made in three independent replications.

\subsubsection{Reducing Sugar Content of Garlic Samples}

Extracts preparing: $100.0 \mathrm{mg}$ of freeze-dried garlic were weighed on an analytical balance (AS 220/X, Radwag, Radom, Poland) into $10 \mathrm{~mL}$ plastic tubes, then $5 \mathrm{~mL}$ of $80 \%$ acetone (Sigma-Aldrich, Poznań, Poland) was added, vortexed (Wizard Advanced IR Vortex Mixer, VELP Scientifica Srl, Usmate, Italy) for $60 \mathrm{~s}$ and finally incubated in an ultrasonic bath $\left(35 \mathrm{kHz}, 30^{\circ} \mathrm{C}\right.$ ) (Bandelin Sonorex RK 255, BANDELIN Electronic GmbH and Co. KG, Berlin, Germany) for $10 \mathrm{~min}$. Then, the samples were centrifuged (MPW-380 R, MPW Med. Instruments, Poland, Warsaw) for $10 \mathrm{~min}$ (temp. $3^{\circ} \mathrm{C}, 6000 \mathrm{rpm}$ ), the clear supernatants $(1.0 \mathrm{~mL})$ were collected into HPLC-vials and analysed.

Reducing sugars (fructose, glucose, sucrose) content in garlic samples were determined by HPLC-method (high-performance liquid chromatography) according to Ponder and Hallmann (2020) [86], using the Shimadzu HPLC kit (USA Manufacturing Inc., Tampa, FL, USA), consisting of two LC-20AD pumps, a CMB-20A system controller, a SIL-20AC column oven and a RID/SPD-M20A spectrometer.

Reducing sugars were identified and separated on a Phenomenex Luna NH2 Chromatography Column (Phenomenex, Shimpol, Warsaw, Poland) under isocratic conditions with a flow rate of $1 \mathrm{~mL} / \mathrm{min}$ using $80 \%$ of acetone with deionized water. The analysis time was $15 \mathrm{~min}$. The reducing sugars (fructose, glucose, sucrose) were identified by the analysis of the retention times of standard substances (purity of 99.9\%) (Sigma-Aldrich, Warsaw, Poland). The content of reducing sugars in the garlic samples were calculated on the basis of the prepared standard curves for standard substances and the results were expressed as $\mathrm{mg} / 100 \mathrm{~g}$ dry matter (d.m.). The determinations were made in three independent replications. Total reducing sugars were calculated as the sum of fructose, glucose and sucrose content and expressed as a g per $100 \mathrm{~g}$ of dry matter (g/100 g d.m.).

\subsubsection{Polyphenolic Content (Phenolic Acids and Flavonoids) of Garlic Samples}

Extracts preparing: $100.0 \mathrm{mg}$ of freeze-dried samples were weighed on an analytical balance (AS 220/X, Radwag, Radom, Poland) into $10 \mathrm{~mL}$ plastic tubes, then $5 \mathrm{~mL}$ of $80 \%$ methanol (Sigma-Aldrich, Poznań, Poland) was added, vortexed (Wizard Advanced IR Vortex Mixer, VELP Scientifica Srl, Usmate, Italy) for $60 \mathrm{~s}$ and finally incubated in an ultrasonic bath $\left(35 \mathrm{kHz}, 30^{\circ} \mathrm{C}\right.$ ) (Bandelin Sonorex RK 255, BANDELIN Electronic GmbH \& Co. KG, Berlin, Germany) for $10 \mathrm{~min}$. After that, the samples were centrifuged (MPW-380 
R, MPW Med. Instruments, Poland, Warsaw) for $15 \mathrm{~min}\left(3^{\circ} \mathrm{C}, 6000 \mathrm{rpm}\right)$. The obtained clear supernatants $(1.0 \mathrm{~mL})$ were collected into HPLC-vials and analysed. The content of selected phenolic acids and flavonoids in garlic samples were determined by HPLCmethod (high-performance liquid chromatography) according to Hallmann et al. [87], using the Shimadzu HPLC kit (USA Manufacturing Inc., Tampa, FL, USA), consisting of two LC-20AD pumps, a CMB-20A system controller, a SIL-20AC autosampler and a SPD-20AV UV-VIS detector.

Polyphenolic compounds were identified and separated on a Synergi Fusion-RP 80i $(250 \times 4.60 \mathrm{~mm})$ Chromatography Column using a two phase flow gradient: acetonitrile/deionised water (55\% and $10 \%$ ) at $\mathrm{pH} 3.00$ with a flow rate of $1.0 \mathrm{~mL} / \mathrm{min}$ and detection at a wavelength of 250-370 $\mathrm{nm}$. The analysis time was $38 \mathrm{~min}$. The phenolic acids and flavonoids content were identified by the analysis of the retention times of standard substances (purity of 99.9\%) (Sigma-Aldrich, Warsaw, Poland).

The content of phenolic acids and flavonoids were calculated on the basis of the prepared standard curves for standard substances and the results were expressed as $\mathrm{mg} / 100 \mathrm{~g}$ of $\mathrm{d} . \mathrm{m}$. The determinations were made in three independent replications. Total phenolic acids and total flavonoids were calculated as the sum of five phenolic acids and six flavonoids fructose, glucose and sucrose content and expressed in g per $100 \mathrm{~g}$ of dry matter (d.m.). The total phenolic acids and total flavonoids content were calculated as the sum of five phenolic acids and six flavonoids, respectively, determined in the study and expressed as a $\mathrm{g}$ per $100 \mathrm{~g}$ of $\mathrm{d} . \mathrm{m}$.

\subsubsection{Total Polyphenol Content and Antioxidant Activity of Garlic Samples}

Extracts preparing: $1.0 \mathrm{~g}$ of freeze-dried samples were weighed on an analytical balance (AS 220/X, Radwag, Radom, Poland) into $50 \mathrm{~mL}$ plastic Falcone tube, then $30.0 \mathrm{~mL}$ distilled water was added, vortexed (Wizard Advanced IR Vortex Mixer, VELP Scientifica Srl, Usmate, Italy) for $60 \mathrm{~s}$ (2000 rpm) and finally incubated in a shaking incubator (IKA KS 4000i Control, IKA ${ }^{\circledR}$ Poland Ltd., Warsaw, Poland) for $60 \mathrm{~min}\left(40{ }^{\circ} \mathrm{C}, 200 \mathrm{rpm}\right)$. After that, the samples were vortexed again for $60 \mathrm{~s}$ and centrifuged (MPW-380 R, MPW Med. Instruments, Poland, Warsaw) for $15 \mathrm{~min}\left(3^{\circ} \mathrm{C}, 10,000 \mathrm{rpm}\right)$. The obtained clear supernatants were designated for the determination of total polyphenol content and the antioxidant activity of garlic samples.

The total polyphenol content was determined according to modified Singleton and Rossi [88] method using the Folin-Ciocalteu (Sigma-Aldrich, Poznan, Poland) reagent. The specified amount of the extracts solution (predetermined by the dilution scheme) was taken into $50 \mathrm{~mL}$ flasks, then $2.5 \mathrm{~mL}$ of Folin-Ciocalteu reagent and $5.0 \mathrm{~mL}$ of $20 \%$ sodium carbonate (Sigma-Aldrich, Poznan, Poland) were added and finally made up to the mark with distilled water. The samples were incubated for $60 \mathrm{~min}$ in room temperature with no light access. The absorbance was measured at the wave length of $\lambda=750 \mathrm{~nm}$, with the use of spectrophotometer (UV-VIS UV-6100A, Metash Instruments Co., Ltd., Shanghai, P. R. China). The results calculated based on the calibration curve for gallic acid (SigmaAldrich, Poznań, Poland) $\left(\mathrm{y}=2.224+0.1304, \mathrm{R}^{2}=0.9995\right)$, were expressed as mg GAE (gallic acid equivalent), i.e., $\mathrm{mg}$ of gallic acid per $1 \mathrm{~g}$ of dry matter (mg GAE/g d.m.). The determinations were performed in six independent replications.

Antioxidant activity in water extracts of the test material was determined by using ABTS $^{+\bullet}\left(2,2^{\prime}\right.$-azino-bis (3-ethylbenzothiazoline-6-sulphonic) acid) (Sigma-Aldrich, Poznań, Poland) radical cation assay according to modified Re et al. (1999) method [89]. A certain amount of the solution of the test extracts $(0.5-1.5 \mathrm{~mL})$ was collected into $10 \mathrm{~mL}$ glass test tubes, which had been previously determined by the designated dilution scheme. Then $3.0 \mathrm{~mL}$ of $\mathrm{ABTS}^{+\bullet}$ radical cations in PBS solution (phosphate buffer solution, Sigma-Aldrich, Poznań, Poland) was added. The absorbance measurement was made exactly after 6 min of incubation in room temperature. The absorbance was measured at the wave length of $\lambda=734 \mathrm{~nm}$, with the use of a spectrophotometer (UV-VIS UV-6100A, Metash Instruments Co., Ltd., Shanghai, P. R. China). The results were calculated based on the calibration curve 
for Trolox (Sigma-Aldrich, Poznań, Poland) $\left(y=-5.7163+0.7021, R^{2}=0.9998\right)$ and were expressed as $\mu \mathrm{M}$ TEAC (Trolox equivalent antioxidant capacity), i.e., the quantity of Trolox $\mu$ mols per $1 \mathrm{~g}$ of dry matter ( $\mu \mathrm{M}$ TEAC $/ 1 \mathrm{~g} \mathrm{~d}$.m) of tested material. The determinations were performed in six independent replications.

\subsubsection{Instrumental Colour Measurement of Garlic Samples}

Instrumental colour measurement of white ( $G$ and $E G$ ) and black (BG and EBG) garlic was performed by computer image analysis using the Visual Analyzer 400 colour analyser (Alpha M.O.S., Toulouse, France). After placing the test samples of powdered garlic in the measuring chamber, controlled upper and lower lighting was applied (preventing the shadow effect). The photos of the samples were taken using a Fujifilm (Fujifilm, Tokyo, Japan) lens with a diameter of $16 \mathrm{~mm}$ and $0.1 \mathrm{~m}$ focal length. Measurements were made in the CIE Lab systems ( $L$-brightness, $+a$-red, $-a$-green, $+b$-yellow, $-b$-blue) and RGB system (R-red, G-green, B-blue). The values for the parameters $L^{*}, a^{*}, b^{*}, \mathrm{R}, \mathrm{G}, \mathrm{B}$ were calculated as weighted averages taking into account the frequency of appearance of individual colour code. Measurements and photos were taken in three independent replications.

\subsubsection{Statistical Analysis}

The data are presented as the mean \pm standard deviation (SD) of two to six independent replications and analysed by one-way ANOVA, followed by Duncan's multiple range test using the statistical programme Statistica 13.0 (Tibco Software Inc., Palo Alto, CA, USA). Differences were considered statistically significant at $p<0.05$ for all assays.

\section{Results and Discussion}

Changes in the appearance of fresh conventional (G) and organic (EG) garlic (bulbs and cloves) during heat treatment ( 45 days, $70^{\circ} \mathrm{C}, 80 \%$ humidity) are presented in Figure 1, while the physicochemical characterization of fresh and black garlic from conventional and organic cultivation are shown in Table 1.

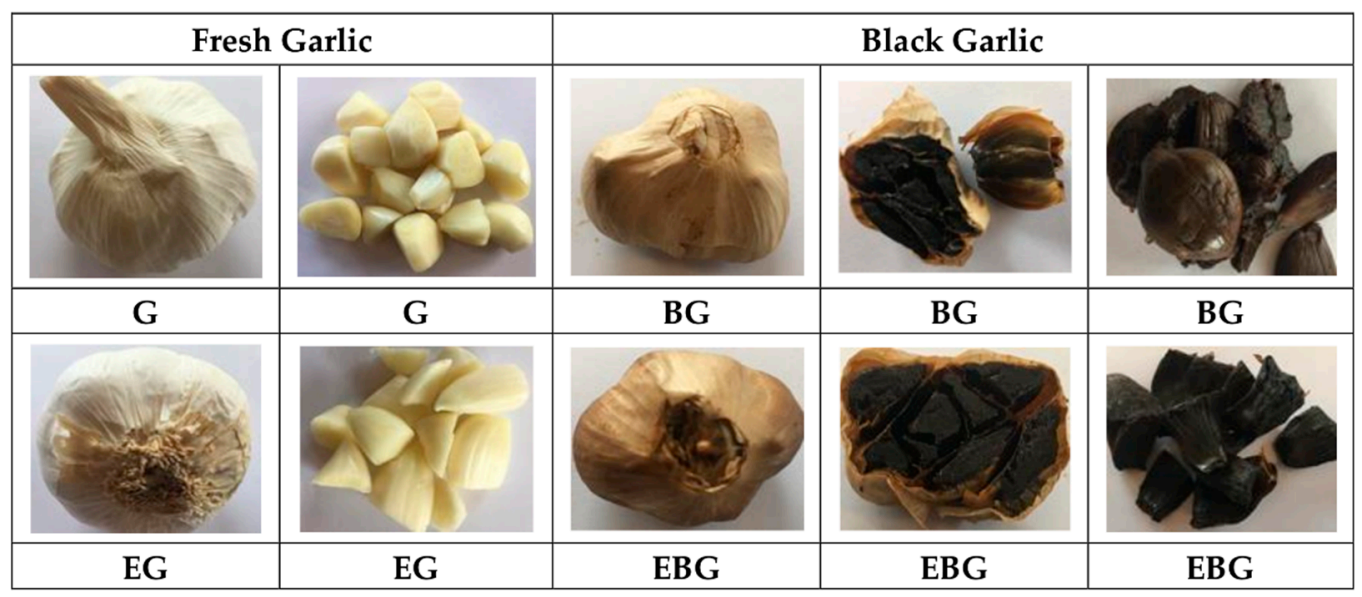

Figure 1. Changes in the appearance of fresh conventional (G) and organic (EG) garlic (bulbs and cloves) during heat treatment ( 45 days, $70{ }^{\circ} \mathrm{C}, 80 \%$ humidity). G—fresh conventional garlic; EG—fresh organic garlic; BG-conventional black garlic; EBG—organic black garlic.

All garlic samples were characterized by significant $(p<0.05)$ variation in dry matter content, with average conventional $(\mathrm{G})$ and organic $(E G)$ white garlic containing approx. $35.17 \pm 4.29 \%$ and black garlic (BG and EBG) about $56.43 \pm 5.69 \%$ of dry matter. The lowest dry matter content was found in conventional white garlic $(G)$ and the highest was found in organic black garlic (EBG). Both white (EG) and black (EBG) organic garlic had a higher dry matter content than conventional garlic (by $6 \%$ and $8 \%$, respectively, for $\mathrm{G}$ and $\mathrm{BG}$ ). The obtained results are similar to results obtained by other authors, who found the dry 
matter content of fresh (white) garlic at the level of 35.79-38.90\% [60,64,70] and showed, as in this study, an increase in the dry matter content of garlic during heat treatment processes. At the same time, the aging process of garlic is accompanied by a decrease in humidity, depending on the conditions of heat treatment. According to this study, during the process of producing black garlic, the water content decreased by about $21 \%$ (from $64.87 \%$ to $43.56 \%$ ), which corresponds to the studies of other authors, who showed a decrease in water content from $62-68 \%$ to $45-54 \%$ [64], or from $64.83 \%$ to $46.56 \%$ [90] in black garlic.

Table 1. Physicochemical characterization of white and black garlic from conventional and organic cultivation.

\begin{tabular}{ccccc}
\hline Sample & G & EG & BG & EBG \\
\hline Dry matter $(\%)$ & $32.13 \pm 0.99^{\mathrm{a}}$ & $38.21 \pm 1.06^{\mathrm{b}}$ & $52.41 \pm 0.92^{\mathrm{c}}$ & $60.46 \pm 1.96^{\mathrm{d}}$ \\
\hline $\mathrm{pH}$ & $6.20 \pm 0.03^{\mathrm{c}}$ & $6.32 \pm 0.07^{\mathrm{d}}$ & $3.95 \pm 0.03^{\mathrm{b}}$ & $3.43 \pm 0.05^{\mathrm{a}}$ \\
\hline${ }^{\circ}$ Brix & $35.60 \pm 0.20^{\mathrm{a}}$ & $37.43 \pm 0.25^{\mathrm{b}}$ & $45.43 \pm 0.47^{\mathrm{c}}$ & $52.10 \pm 0.20^{\mathrm{d}}$ \\
\hline $\begin{array}{c}\text { Fructose } \\
\text { g/100 g d.m. }\end{array}$ & $9.36 \pm 0.13^{\mathrm{a}}$ & $10.26 \pm 0.14^{\mathrm{a}}$ & $31.05 \pm 1.34^{\mathrm{b}}$ & $36.09 \pm 0.31^{\mathrm{c}}$ \\
\hline $\begin{array}{c}\text { Glucose } \\
\text { g/100 g d.m. }\end{array}$ & $2.12 \pm 0.05^{\mathrm{a}}$ & $2.44 \pm 0.02^{\mathrm{a}}$ & $4.84 \pm 0.28^{\mathrm{b}}$ & $5.95 \pm 0.75^{\mathrm{c}}$ \\
\hline $\begin{array}{c}\text { Sucrose } \\
\text { g/100 g d.m. }\end{array}$ & $0.02 \pm 0.00^{\mathrm{a}}$ & $0.32 \pm 0.01^{\mathrm{b}}$ & $3.11 \pm 0.12^{\mathrm{d}}$ & $2.93 \pm 0.04^{\mathrm{c}}$ \\
\hline $\begin{array}{c}\text { Total reducing sugars } \\
\text { g/100 g d.m. }\end{array}$ & $11.50 \pm 0.15^{\mathrm{a}}$ & $13.02 \pm 0.15^{\mathrm{b}}$ & $39.00 \pm 1.17^{\mathrm{c}}$ & $45.00 \pm 0.47^{\mathrm{d}}$ \\
\hline
\end{tabular}

Values are means \pm standard deviation $(\mathrm{n}=3){ }^{\mathrm{a}-\mathrm{d} \text { - different letters in the same line are significantly different }}$ (Duncan's test, $p<0.05$ ). G—conventional white garlic; EG—organic white garlic; BG—conventional black garlic; EBG—organic black garlic.

Water content is a key factor influencing both the textural parameters of black garlic, as well as the activity of enzymes and the rate of chemical, biochemical and physical transformations, which ultimately determine the nutritional and biological value of black garlic [8]. According to the literature, the optimum water content of black garlic should be in the range of $45-54 \%$. Such a product is characterised by the most favourable texture (elasticity and softness) [71]. Values in the range of $35-40 \%$ give a less flexible product and values below 35\% give a hard, brittle and battered product $[60,70]$. The moisture content of black garlic is affected by heat treatment conditions. At a higher temperature, the moisture in the product decreases more rapidly [70], while the higher relative humidity of the process results in a higher moisture content of black garlic [91]. Initially, the decrease in moisture in the processed product proceeds slowly due to the high relative humidity and then it proceeds very quickly due to evaporation at a high temperature, after which it can again slow down or even stop due to degradation of water-retaining compounds, such as fructans, which, during the aging process of garlic, decompose into simple sugars or disaccharides $[67,70,92,93]$.

As shown in Table 1, all garlic samples had significantly $(p<0.05)$ different content of reducing sugars. The sum of these compounds was significantly lower in white garlic and averaged $12.26 \pm 1.08 \mathrm{mg} / 100 \mathrm{~g} \mathrm{d.m.} \mathrm{(G} \mathrm{and} \mathrm{EG)} \mathrm{as} \mathrm{compared} \mathrm{with} \mathrm{black} \mathrm{garlic}$ (BG and EBG), in which it averaged $42.00 \pm 4.24 \mathrm{mg} / 100 \mathrm{~g}$ d.m., which means that, as a result of the garlic aging process applied, the sum of free reducing sugars increased more than 3.5 times. The results obtained in this study are reflected in the studies by other authors who showed approx. a four-fold [67], 6.7-fold [94], 10-fold [73], 30-fold [93] and even 54-fold [71] increase in the amount of these compounds in black garlic as compared with fresh, unprocessed garlic. Studies have also shown that during thermal processing of black garlic, not only the sum of reducing sugars, but also the carbohydrate profile has changed. According to the literature, the carbohydrate content of fresh garlic can be from $22 \%$ to $26 \%$ of fresh weight or up to $77 \%$ of dry weight. These carbohydrates are 
mainly polysaccharides and oligo-and monosaccharides in a small amount [7]. During heat treatment applied in the production of black garlic, polysaccharides are gradually broken down to oligosaccharides, disaccharides and, above all, to monosaccharides, mainly glucose and fructose, due to thermal and enzymatic degradation catalysed by fructan EXOhydrolase present in garlic [8,74-76]. Of the reducing sugars identified in these studies, the largest changes were found for fructose. The average content of this sugar in white garlic samples did not differ for G and EG $(9.81 \pm 0.64 \mathrm{~g} / 100 \mathrm{~g} \mathrm{d.m}$.), while in black garlic it was approx. 3.4-fold higher (it averaged $33.57 \pm 3.56 \mathrm{~g} / 100 \mathrm{~g} \mathrm{~d} . \mathrm{m}$.), with the highest fructose content $(p<0.05)$ found in organic black garlic EBG $(36.09 \pm 0.31 \mathrm{mg} / 100 \mathrm{~g}$ d.m.). The obtained data are similar to the results of the studies done by other authors $[67,79]$, who showed a more than five-fold increase in the amount of this sugar in black garlic. The authors explain the dynamics of these changes by the decomposition of fructose present in fresh, unprocessed garlic, the amount of which decreases dramatically (by $84.79 \%$ ) during the ripening process of garlic, as a result of the enzymatic decomposition of fructan under the influence of hydrolase into glucose and fructose [67]. Others showed a gradual decrease in the content of polysaccharides by approx. 69\% [71] during the heat treatment process of black garlic. In our study, a similar trend of changes was found in the glucose content. White garlic from conventional cultivation $(\mathrm{G})$ did not differ from organic garlic (EG) $(p<0.05)$ in terms of the content of this compound (on average $2.28 \pm 0.23 \mathrm{~g} / 100 \mathrm{~g}$ ), while the heat treatment processes applied resulted in an approximately more than 1.5-fold increase in the glucose content of black garlic $(5.39 \pm 0.79 \mathrm{~g} / 100 \mathrm{~g}$ on average in BG and $\mathrm{EBG})$, with its highest $(5.95 \pm 0.75 \mathrm{~g} / 100 \mathrm{~g}$ d.m.) content in EBG. The trend obtained is in line with the studies by other authors, who find the largest share of reducing sugars (fructose and glucose) in black garlic $[75,76,79,80]$. Of the reducing sugars identified, the lowest content was found for sucrose. Organic garlic (EG) had a significantly $(p<0.05)$ higher content $(0.32 \pm 0.01 \mathrm{mg} / 100 \mathrm{~g}$ d.m. $)$ of reducing sugars than conventional garlic $(0.02 \pm 0.00 \mathrm{mg} / 100 \mathrm{~g}$ d.m. $)$. The heat treatment process applied resulted in a significant $(p<0.05)$, more than 17.7-fold, increase in the content of sucrose in black garlic, with a significantly higher content of this component in BG ( $3.11 \pm 0.12 \mathrm{mg} / 100 \mathrm{~g}$ d.m.). However, taking to account the mutual proportions of individual reducing sugars in their total quantity in the product, the share of sucrose did not exceed $2.5 \%$ for white garlic and $8 \%$ for black garlic, which has been confirmed in the studies by other authors $[75,76,79,80]$. In this study, the main reducing sugars in black garlic were glucose $(12.41 \%$ in BG and $13.22 \%$ in EBG, respectively) and fructose (79.6\% in BG and 80.2\% in EBG, respectively). Given that the sweetness of fructose is more than 2 times higher than that of glucose and more than 1.7 times higher than that of sucrose [95], the high sweetness of black garlic is attributed to the high content of these sugars, in particular fructose $[67,72]$.

The available literature data lacks comparative data on changes in the content of reducing sugars in organic and conventional garlic. This study found a significantly $(p<0.05)$ higher content (approx. 13.3\%) of reducing sugars in organic garlic than in conventionally grown garlic, both in white garlic EG (approx. 11.7\%) and in black garlic EBG produced in the 45 -day heat treatment (at $70{ }^{\circ} \mathrm{C}$ and $80 \%$ relative humidity). According to the available literature, the content of reducing sugars in black garlic depends on the variety, conditions and time of storage, pre-treatment [96], but above all on the conditions of the heat treatment process and can vary in wide ranges, depending on the temperature, humidity, or processing time $[76,77,80,81]$. The content of reducing in black garlic depends mainly on two factors: decomposition of polysaccharides and consumption of reducing sugars in the Maillard reactions occurring during heat treatment of garlic [70]. Heat treatment at different temperatures results in a different tendency of changes in the sugar content [71,74]. In general, the content of these compounds constantly increases with an increasing temperature during the entire process conducted in the $60-70{ }^{\circ} \mathrm{C}$ range, which is explained by a higher rate of sugar production from the hydrolytic decomposition of polysaccharides rather than by consumption of sugars in the Maillard reactions under these thermal conditions [70]. When heat treatment of black garlic is carried out in higher temperature ranges $\left(80-90^{\circ} \mathrm{C}\right)$, 
a similar increasing tendency is observed only at the early stage of processing. This is associated with a greater consumption of reducing sugars in the Maillard reactions, whose rate is increasing rapidly in these temperature ranges. Thus, heat treatment carried out at high temperatures $\left(90^{\circ} \mathrm{C}\right)$ reduces the content of reducing sugars. The second key factor determining the increase in the content of free reducing sugars in black garlic is the relative humidity present during its processing. According to the literature, high relative humidity is accompanied by an intensive increase in the content of reducing sugars derived from hydrolysis of polysaccharides at high temperatures [8]. In addition, high humidity slows down the rate of the Maillard reaction and, thus, increases the sugar content $[8,97]$.

According to this study, the content of soluble solids was consistent with the content of reducing sugars and amounted to an average of $36.52 \pm 1.30{ }^{\circ}$ Brix in white garlic (total for $G$ and $E G)$, while in organic garlic $(E G)$ it was significantly $(p<0.05)$ higher than in conventional garlic $(G)$. The heat treatment processes applied to garlic resulted in a significant $(p<0.05)$ increase in the level of soluble solids in black garlic to an average of $48.77 \pm 4.71^{\circ}$ Brix (total for BG and EBG), while the increase in the content of reducing sugars was significantly higher in organic black garlic than in conventional black garlic. The results of our research coincide with those obtained by other authors. In fresh, unprocessed garlic, Toledano-Medina et al. (2019) [93] showed the content of soluble solids at the level of $40.47 \%$, and during thermal processing of garlic $\left(60{ }^{\circ} \mathrm{C}\right.$ temperature and $90 \%$ relative humidity), increase in the amount of these compounds depended on the time of heat treatment. During the first 13 days of aging, they found no change in the content of soluble solids, but after 32 and 45 days of garlic processing, they showed a significant increase in the level of these components (to $43.17 \%$ and $45.67 \%$, respectively). Other authors showed the content of soluble solids in fresh garlic in the range of $37.33-40.50 \%$ and their increase directly proportional to the temperature $\left(72{ }^{\circ} \mathrm{C}, 75^{\circ} \mathrm{C}\right.$ and $\left.78^{\circ} \mathrm{C}\right)$ and time of garlic processing (up to 33 days) at a relative humidity of about $90 \%$, up to $50.33 \%$. In addition, these authors showed that at the end of heat treatment carried out at $78{ }^{\circ} \mathrm{C}$ and $75{ }^{\circ} \mathrm{C}$, the content of soluble solids was lower $(44.00 \%$ and $45.25 \%$, respectively) in whole garlic heads than in peeled garlic cloves subjected to the same processing conditions $(45.33 \%$ and 47.5\%, respectively) [68]. In addition, Toledano-Medina et al. (2019) [93] also showed statistically significant differences in the level of these compounds in the three studied varieties: Chinese Spring, California White and Spanish Roja, both in fresh material (30.5\%, $40.67 \%$ and $43.5 \%$, respectively) and in black garlic produced from them $(42.5 \%, 48.6 \%$ and $55.75 \%$, respectively) during a 34-day heat treatment $\left(72{ }^{\circ} \mathrm{C}, 90 \%\right.$ humidity), which suggests that not only the conditions of the black garlic production process, but also the genotypic and environmental conditions, including the method of cultivation, determine the amount of compounds in the raw material and the changes in their content during the processes applied.

Taking into account the obtained results for all analysed garlic samples, a statistically significant $(p<0.05)$ correlation was found between the total reducing sugars and total soluble solids ( ${ }^{\circ}$ Brix $),\left(\mathrm{R}^{2}=0.97\right)$, which means that with an increased in the content of reducing sugars, the content of soluble solids increases and this relationship was practically complete.

During heat treatment leading to the production of black garlic, the $\mathrm{pH}$ level also changes significantly. According to the studies (Table 1), the average $\mathrm{pH}$ of fresh, unprocessed garlic was $6.26 \pm 0.09$ (total for $G$ and EG), while in black garlic it decreased significantly $(p<0.05)$ to an average of $3.69 \pm 0.36$ (total for BG and EBG), with the lowest value in organic black garlic (3.43). Our research is confirmed in the studies by other authors, who showed the $\mathrm{pH}$ of fresh garlic at the level of 6.13 and a decrease in this parameter to a value of approx. 4.00 under the influence of heat treatment ( 90 days, $55^{\circ} \mathrm{C}, 80 \%$ relative humidity) [79]. Toledano-Medina et al. (2016) [68] reported that the $\mathrm{pH}$ of fresh, unprocessed garlic heads (5.93 \pm 0.01$)$ and cloves $(6.31 \pm 0.07)$ under the influence of the aging process carried out during 33 days ( $90 \%$ relative humidity) was significantly reduced (to $3.49 \pm 0.06$ and $3.52 \pm 0.03$, respectively, for black garlic heads and cloves), depending 
on the temperature applied. At a higher temperature, the $\mathrm{pH}$ was lower. Additionally, Bae et al. (2016) [64] noted significant decreases in the $\mathrm{pH}$ of fresh garlic (6.42) during heat treatment (45 days under different thermal conditions), to a $\mathrm{pH}$ of about $5.00\left(45^{\circ} \mathrm{C}\right)$ and up to approx. $3.05\left(85^{\circ} \mathrm{C}\right)$. Those studies suggest that both the higher temperature of garlic heat treatment and the longer duration of its use lead to a lower $\mathrm{pH}$ in the processed product.

As indicated by the literature, the low $\mathrm{pH}$ of black garlic ensures its relatively long shelf life and high microbiological stability. A pH below 4.2 significantly reduces proliferation of anaerobic bacteria and growth of microorganisms responsible for food poisoning, and the high temperature accompanying the process of obtaining black garlic destroys the spores of bacteria and fungi, reducing food spoilage [98]. According to the literature, a low $\mathrm{pH}$ is usually accompanied by high acidity, mainly due to the high content of organic acids. Zhang et al. (2012) [70] showed a significant increase in the acidity of fresh garlic $(4.6 \mathrm{~g} / \mathrm{kg})$ during heat treatment to $33.63 \mathrm{~g} / \mathrm{kg}, 37.5 \mathrm{~g} / \mathrm{kg}, 30.96 \mathrm{~g} / \mathrm{kg}$ and $36.37 \mathrm{~g} / \mathrm{kg}$ at $60^{\circ} \mathrm{C}, 70{ }^{\circ} \mathrm{C}, 80^{\circ} \mathrm{C}$ and $90^{\circ} \mathrm{C}$, respectively. The increased content of organic acids in black garlic not only determines the microbiological stability and taste qualities (giving the product a characteristic sweet and sour taste), but also facilitates hydrolysis of proteins and polysaccharides [99]. The many times higher acidity of black garlic compared to white garlic is due both to the high consumption of amino groups of amino acids during the Maillard reaction, as well as to the production of short-chain carboxylic acids as a result of degradation of dicarbonyl compounds and Amadori products [100,101]. The increasing number of products of the Maillard reaction, resultant from oxidation of aldehyde groups in aldoses, leads to an increase in the content of organic acids, resulting in a decrease in $\mathrm{pH}[77-79,102-104]$. Thus, the lower $\mathrm{pH}$ and higher acidity of black garlic are also closely related to the browning reactions. The obtained test results for all analysed garlic samples showed a statistically significant $(p<0.05)$ correlation between the soluble solids content ( ${ }^{\circ}$ Brix) and the $\mathrm{pH}\left(\mathrm{R}^{2}=0.96\right)$, which means that with the increase in soluble solids content, the $\mathrm{pH}$ of the tested samples decreased and it was practically complete.

The literature lacks information on the comparison of bioactive content (phenolic acids, flavonoids and total polyphenols) and antioxidant activity in black garlic from conventional and organic cultivation. Therefore, in this paper, the content of phenolic compounds and antioxidant activity of white and black, organic and conventional garlic were studied and the results are presented in Table 2.

The average content of the sum of the determined phenolic acids in the test samples of white garlic (G and EG) was $49.01 \pm 6.21 \mathrm{mg} / 100 \mathrm{~g}$ d.m. White garlic from organic cultivation (EG) was characterised by a significantly $(p<0.05)$ higher content of these components $(54.66 \pm 0.07 \mathrm{mg} / 100 \mathrm{~g} \mathrm{d.m}$.) than white garlic from conventional cultivation (43.35 $\pm 0.63 \mathrm{mg} / 100 \mathrm{~g}$ d.m.).

The dominant phenolic acids in white garlic, both conventional (G) and organic (EG), were derivatives of hydroxycinnamic acid $(34.06 \mathrm{mg} / 100 \mathrm{~g}$ d.m. and $42.52 \mathrm{mg} / 100 \mathrm{~g}$ d.m., respectively), and the most abundant acids were p-coumaric acid $(20.66 \pm 0.49 \mathrm{mg} / 100 \mathrm{~g}$ d.m. in $\mathrm{G}$ and $23.80 \pm 0.06 \mathrm{mg} / 100 \mathrm{~g} \mathrm{d.m.} \mathrm{in} \mathrm{EG)} \mathrm{and} \mathrm{gallic} \mathrm{acid} \mathrm{(9.29} \pm 0.10 \mathrm{mg} / 100 \mathrm{~g} \mathrm{d.m}$. in $\mathrm{G}$ and $12.14 \pm 0.01 \mathrm{mg} / 100 \mathrm{~g} \mathrm{~d} . \mathrm{m}$. in EG). The results obtained differed significantly from those in the literature, whose authors report fresh garlic's greatest share of caffeic acid, followed by ferulic, vanillin and p-hydroxybenzoate acid [8]. These differences can be caused by many factors, ranging from species and variety differences, to environmental differences, such as growing and harvest conditions, climate, season, agricultural practices and cultivation systems [84]. As a result of applied heat treatment processes, the content of phenolic acids in BG significantly increased (to $80.67 \pm 6.94 \mathrm{mg} / 100 \mathrm{~g} \mathrm{~d} . \mathrm{m}$. on average in BG and EBG), and the highest content of these bioactive compounds was found in organic black garlic ( $87.00 \pm 0.41 \mathrm{mg} / 100 \mathrm{~g} \mathrm{d.m.).} \mathrm{The} \mathrm{available} \mathrm{literature} \mathrm{confirms} \mathrm{the} \mathrm{upward} \mathrm{trend}$ in the content of phenolic acids observed in our study. Authors show a 4-8-fold increase in the content of these compounds during heat treatment of black garlic [55,64,68,73,77]. In the study by Kim et al., (2013) [55] hydroxycinnamic acid derivatives predominated in black garlic at various stages of its processing, just as in this study, which found that in 
conventional (BG) and organic (EGB) black garlic they accounted for $82.5 \%$ and $81.1 \%$ of all phenolic acids, respectively. As in fresh garlic, the dominant acid was p-coumaric acid $(26.64 \pm 0.47 \mathrm{mg} / 100 \mathrm{~g} \mathrm{~d} . \mathrm{m}$. in BG and $28.03 \pm 0.12 \mathrm{mg} / 100 \mathrm{~g} \mathrm{~d} . \mathrm{m}$. in EBG). The second place was occupied by chlorogenic acid (respectively, $21.56 \pm 0.53 \mathrm{mg} / 100 \mathrm{~g} \mathrm{~d} . \mathrm{m}$. in BG and $25.29 \pm 0.52 \mathrm{mg} / 100 \mathrm{~g} \mathrm{~d} . \mathrm{m}$. in EBG). The results of our study are consistent with those of other authors, who also showed the highest proportion of p-coumaric and o-coumaric acids out of all phenolic acids in black garlic, as well as their largest (14-fold) increase during its heat treatment [55]. The phenolic acid present in the lowest concentration in both white and black garlic was ferulic acid. Its average content in white garlic (G and EG) was only $0.71 \pm 0.06 \mathrm{mg} / 100 \mathrm{~g}$ d.m., and in black garlic (BG and EBG) it was $0.66 \pm 0.09 \mathrm{mg} / 100 \mathrm{~g}$ d.m. Similar results were obtained by Martínez-Casas et al. (2017) [74] without statistically significant changes in the content of ferulic acid in the process of black garlic production. The literature lacks information on the comparison of the composition and proportion of phenolic acids in conventional and organic black garlic, and the existing data on changes in the content of these compounds during heat treatment of black garlic are insufficient and diverse. As suggested by some authors, the differences in the share of individual phenolic acids at different stages of heat treatment most likely result from different mechanisms of their synthesis and metabolism during fermentation processes [55] and the conditions of the process itself. According to other authors, a several, and even many times higher, content of phenolic acids in black garlic (compared to unprocessed garlic) is due to their easier release from the tissue matrix under the influence of a high temperature which damages cell walls and vacuoles, and to the high stability of these chemical forms as compared with other phenolic substances. For the same reason, there is also an increase in the level of other phenolic compounds, e.g., flavonoids, during long-term heat treatment of black garlic (at a high temperature and humidity) [55,84,105-107].

As shown in Table 2, the tested samples had a significant $(p<0.05)$ variation in flavonoid content. White organic garlic EG showed a significantly higher (43.13 $\pm 0.20 \mathrm{mg} / 100 \mathrm{~g}$ d.m.) flavonoid content than white garlic from conventional cultivation system $\mathrm{G}(37.75 \pm 0.54 \mathrm{mg} / 100 \mathrm{~g}$ d.m.). During the 45 -day heat treatment of garlic (at $70{ }^{\circ} \mathrm{C}$ and $80 \%$ relative humidity), there was a significant $(p<0.05)$ increase in the content of flavonoids $(62.94 \pm 5.65 \mathrm{mg} / 100 \mathrm{~g}$ d.m. on average in BG and EBG), with their highest concentration observed in organic black garlic EBG (68.08 $\pm 0.46 \mathrm{mg} / 100 \mathrm{~g} \mathrm{d.m}$.). The results obtained in this study coincide with the results of other authors who showed an 1-5-fold increase in the content of these compounds, depending on the time and conditions of the aging process of black garlic $[55,73,75]$. However, there is little data in the available literature on the proportion of individual flavonoids in black garlic, and it lacks information on the comparison of the content of selected catechins or flavonols in organic and conventional black garlic. According to this study, the level of catechins in both white and black garlic was at a similar level and amounted to $18.46 \pm 0.73 \mathrm{mg} / 100 \mathrm{~g} \mathrm{~d} . \mathrm{m}$. (total for G and EG) and $17.90 \pm 0.72 \mathrm{mg} / 100 \mathrm{~g}$ d.m. (total for BG and EBG), respectively. Both white and black garlic were dominated by catechins $(9.54 \pm 0.07 \mathrm{mg} / 100 \mathrm{~g}$ d.m. on average in $\mathrm{G}$ and EG and $10.30 \pm 0.47 \mathrm{mg} / 100 \mathrm{~g}$ d.m. in BG and EBG), and epicatechin was present at approximately 2.5-fold lower concentrations (in all garlic variants studied). The content of catechins and epicatechins was found to be significantly $(p<0.05)$ higher in organic garlic, both white and processed black. The only catechin reported to be higher in conventional garlic than in organic garlic, both fresh (unprocessed) and processed (black), was epigallocatechin gallusate. There was also a significant $(p<0.05)$ decrease in the content of this phenolic compound during heat treatment of garlic, by $28.17 \%$ in BG and $32.92 \%$ in EBG, respectively. As for flavonols, significant $(p<0.05)$ differences were found in both white and black garlic. White organic garlic was characterised by a significantly higher content of flavonols (24.15 mg/100 g d.m.) than conventional garlic (19.81 mg/100 g d.m.). Organic black garlic EBG had a significantly higher content of these compounds (49.68 mg/100 g d.m.) than conventional black garlic BG $(40.41 \mathrm{mg} / 100 \mathrm{~g} \mathrm{~d} . \mathrm{m}$.). The heat treatment processes applied resulted in a more than two-fold increase in the content of flavonols, both in BG and EBG. 
The main flavonol in both white (organic and conventional) and black garlic was quercetin, which accounted for approx. 65\% (G), 61\% (EG), 72.32\% (BG), and $68.13 \%$ (EBG) of all flavonols. There was also a wide variation in the content of kaempferol. Fresh organic garlic contained more than 1.5 more $(6.01 \pm 0.03 \mathrm{mg} / 100 \mathrm{~g} \mathrm{~d}$.m.) kaempferol than fresh conventional garlic ( $3.67 \pm 0.02 \mathrm{mg} / 100 \mathrm{~g} \mathrm{~d} . \mathrm{m}$.). This trend was also maintained during heat treatment of garlic, because organic black garlic was characterised by a significantly higher content of kaempferol (12.12 $\pm 0.50 \mathrm{mg} / 100 \mathrm{~g} \mathrm{d.m}$.) than conventional black garlic $(7.66 \pm 0.05 \mathrm{mg} / 100 \mathrm{~g}$ d.m.). The heat treatment processes applied contributed to an approx. 2 -fold increase in kaempferol content in black garlic compared to unprocessed white garlic. Miricetin accounted for the smallest proportion of total flavonols. On average, it was shown to be $3.27 \pm 0.02 \mathrm{mg} / 100 \mathrm{~g} \mathrm{~d} \mathrm{~m}$. in white garlic without any significant differences in $\mathrm{G}$ and EG. The heat treatment processes applied resulted in a small but significant $(p<0.05)$ increase in the amount of this flavonoid in black garlic $(3.61 \pm 0.13 \mathrm{mg} / 100 \mathrm{~g}$ d.m. on average in $B G$ and $E B G)$, with its highest content found in EBG (3.71 $\pm 0.05 \mathrm{mg} / 100 \mathrm{~g}$ d.m.).

Table 2. Content of phenolic compounds and antioxidant activity of white and black, organic and conventional garlic.

\begin{tabular}{|c|c|c|c|c|}
\hline Bioactive Compounds & G & EG & BG & EBG \\
\hline $\begin{array}{l}\text { Total phenolic acids } \\
\text { mg/100 g d.m. }\end{array}$ & $43.35 \pm 0.63^{a}$ & $54.66 \pm 0.07^{b}$ & $74.34 \pm 0.47^{\mathrm{c}}$ & $87.00 \pm 0.41^{\mathrm{d}}$ \\
\hline $\begin{array}{l}\text { Gallic acid } \\
\text { mg/100 g d.m. }\end{array}$ & $9.29 \pm 0.10^{a}$ & $12.14 \pm 0.01^{\mathrm{b}}$ & $13.01 \pm 0.04^{b}$ & $16.42 \pm 0.12^{c}$ \\
\hline $\begin{array}{l}\text { Chlorogenic acid } \\
\text { mg/100 g d.m. }\end{array}$ & $6.75 \pm 0.23^{a}$ & $9.03 \pm 0.06^{b}$ & $21.56 \pm 0.53^{c}$ & $25.29 \pm 0.52^{d}$ \\
\hline $\begin{array}{l}\text { Caffeic acid } \\
\text { mg/100 g d.m. }\end{array}$ & $5.98 \pm 0.05^{\mathrm{a}}$ & $8.93 \pm 0.03^{b}$ & $12.55 \pm 0.02^{\mathrm{c}}$ & $16.54 \pm 0.02^{d}$ \\
\hline $\begin{array}{l}\text { P-coumaric acid } \\
\text { mg/100 g d.m. }\end{array}$ & $20.66 \pm 0.49^{a}$ & $23.80 \pm 0.06^{\mathrm{b}}$ & $26.64 \pm 0.47^{c}$ & $28.03 \pm 0.12^{\mathrm{d}}$ \\
\hline $\begin{array}{l}\text { Ferulic acid } \\
\text { mg/100 g d.m. }\end{array}$ & $0.67 \pm 0.02^{b}$ & $0.75 \pm 0,05^{\mathrm{c}}$ & $0.59 \pm 0.01^{\mathrm{a}}$ & $0.72 \pm 0.02^{b c}$ \\
\hline $\begin{array}{l}\text { Total flavonoids } \\
\text { mg/100 g d.m. }\end{array}$ & $37.75 \pm 0.54^{\mathrm{a}}$ & $43.13 \pm 0.20^{b}$ & $57.80 \pm 0.55^{c}$ & $68.08 \pm 0.46^{\mathrm{d}}$ \\
\hline $\begin{array}{l}\text { Catechin } \\
\text { mg/100 g d.m. }\end{array}$ & $9.49 \pm 0.03^{\mathrm{a}}$ & $9.59 \pm 0.01^{b}$ & $9.97 \pm 0.03^{c}$ & $10.64 \pm 0.03^{\mathrm{d}}$ \\
\hline $\begin{array}{l}\text { Epicatechin } \\
\text { mg/100 g d.m. }\end{array}$ & $3.67 \pm 0.01^{\mathrm{a}}$ & $3.74 \pm 0.02^{b}$ & $3.86 \pm 0.04^{\mathrm{c}}$ & $3.98 \pm 0.02^{d}$ \\
\hline $\begin{array}{l}\text { Gallate epigallocatechin } \\
\text { mg/100 g d.m. }\end{array}$ & $4.79 \pm 0.02^{\mathrm{c}}$ & $5.65 \pm 0.03^{d}$ & $3.57 \pm 0.02^{\mathrm{a}}$ & $3.79 \pm 0.02^{b}$ \\
\hline $\begin{array}{c}\text { Myricetin } \\
\text { mg/100 g d.m. }\end{array}$ & $3.26 \pm 0.01^{\mathrm{a}}$ & $3.29 \pm 0.01^{\mathrm{a}}$ & $3.52 \pm 0.06^{b}$ & $3.71 \pm 0.05^{c}$ \\
\hline $\begin{array}{l}\text { Quercetin } \\
\text { mg/100 g d.m. }\end{array}$ & $12.88 \pm 0.53^{a}$ & $14.86 \pm 0.24^{b}$ & $29.22 \pm 0.58^{c}$ & $33.85 \pm 0.03^{d}$ \\
\hline $\begin{array}{l}\text { Kaempferol } \\
\text { mg/100 g d.m. }\end{array}$ & $3.67 \pm 0.02^{\mathrm{a}}$ & $6.01 \pm 0.03^{b}$ & $7.66 \pm 0.05^{\mathrm{c}}$ & $12.12 \pm 0.50^{\mathrm{d}}$ \\
\hline $\begin{array}{l}\text { Total polyphenol } \\
\text { content } \\
\text { mg GAE/g d.m. }\end{array}$ & $6.06 \pm 0.06^{a}$ & $8.08 \pm 0.14^{b}$ & $13.64 \pm 0.10^{c}$ & $17.24 \pm 0.23^{d}$ \\
\hline $\begin{array}{l}\text { Antioxidant activity } \\
\mu \mathrm{mol} \text { TEAC/g d.m. }\end{array}$ & $303.96 \pm 0.87^{\mathrm{a}}$ & $376.19 \pm 2.32^{b}$ & $707.28 \pm 2.72^{c}$ & $828.42 \pm 5.84^{d}$ \\
\hline
\end{tabular}

Values are means \pm standard deviation $(\mathrm{n}=3){ }^{\mathrm{a}-\mathrm{d} \text { - different letters in the same line are significantly different }}$ (Duncan's test, $p<0.05$ ). G—conventional white garlic; EG—organic white garlic; BG—conventional black garlic; EBG—organic black garlic. 
This study showed a high level of total polyphenolic compounds. As shown in Table 2, white garlic was characterised by an average content of these compounds (at the level of $7.06 \pm 1.41 \mathrm{mg}$ GAE/G d.m.), while organic garlic (G) contained significantly $(p<0.05)$ more total polyphenols $(8.08 \pm 0.14 \mathrm{mg}$ GAE $/ \mathrm{g}$ d.m. $)$ than conventional garlic EG $(6.06 \pm 0.06 \mathrm{mg} \mathrm{GAE} / \mathrm{g}$ d.m.). The results obtained are similar to the literature data, according to which the content of total polyphenols in fresh garlic ranges from 3.4 to $10.8 \mathrm{mg}$ GAE/g d.m., averaging $6.5 \mathrm{mg} \mathrm{GAE} / \mathrm{g}$ d.m. [8]. The use of long-term heat treatment of garlic resulted in a significant increase in the level of phenolic compounds in black garlic (up to $15.44 \pm 2.55 \mathrm{mg}$ GAE/g d.m. on average), with the highest content of these bioactive compounds in organic black garlic (17.24 $\pm 0.23 \mathrm{mg} \mathrm{GAE} / \mathrm{g} \mathrm{d.m}$.). The results of our study coincide with those of other authors, who showed a 3 to 10 times higher content of total polyphenolic compounds in black garlic than in fresh garlic, depending on the conditions of the aging process of garlic (time, temperature and relative humidity), as well as on the form in which garlic was aging (heads/cloves) [55,68,71-73,84].

As a result, the increase in the amount of phenolic compounds during long-term (45 days) heat treatment of garlic under conditions of high temperature $\left(70{ }^{\circ} \mathrm{C}\right.$ ) and relative humidity $(80 \%)$ was accompanied by a more than 2.2 times higher antioxidant activity (measured by the ability to deactivate synthetic cation agents ABTS $^{+\bullet}$ ) of black garlic compared to that of white garlic. White garlic from organic cultivation showed an approx. $23.76 \%$ higher antioxidant activity than garlic from conventional cultivation. A similar relationship was found for black garlic. Organic garlic EBG was characterised by an approx. $17.13 \%$ higher antioxidant activity than conventional black garlic (BG). The results obtained are confirmed in the studies by other authors, although they usually obtained a much higher increase in the antioxidant capacity of black garlic $[70,82,83]$, which is due to the different conditions of the aging process of garlic, primarily temperature.

Bae et al. (2014) [64] found approx. a 3.6-fold increase in antioxidant potential of black garlic produced at $40{ }^{\circ} \mathrm{C}$ and a seven-fold increase in this parameter at $80{ }^{\circ} \mathrm{C}$. A similar correlation between the increase in antioxidant activity and aging temperature of garlic was shown by other authors, who state that the temperature of $72{ }^{\circ} \mathrm{C}$ seems to be the most optimal. In addition, they showed that the antioxidant capacity of black garlic processed in the form of cloves was 6.5 times higher, and in the form of whole heads it was as much as 9.5 times higher as compared with unprocessed garlic [68,95]. Still others investigated the dynamics of changes in antioxidant properties of black garlic over time, showing that during the first 21 days of heat treatment antioxidant properties of garlic grow intensively (approx. two times), then, depending on the temperature and humidity, they stabilise and may even decrease [73]. According to our study, the system of cultivation and the qualitative and quantitative composition of the raw material used are also important here, because as for both polyphenolic compounds and their antioxidant properties, white, unprocessed garlic from organic cultivation contains more bioactive compounds (total polyphenols, phenolic acids, and flavonoids), which results in their higher content and higher antioxidant activity obtained in the process of long-lasting heat treatment of organic black garlic. The obtained test results for all analyzed garlic samples showed a statistically significant $(p<0.05)$ correlation between the antioxidant activity, measured by the ability to deactivate synthetic $\mathrm{ABTS}^{+\bullet}$ cationic radicals, and the total polyphenol content $\left(\mathrm{R}^{2}=0.95\right)$, which means that the relationship between the tested parameters was practically complete.

The antioxidant properties are attributed in particular to polyphenolic compounds, which repeatedly increase their content during the aging process of garlic, but also to organosulphuric compounds, being derivatives of alliin and allicin (sulphides, disulphides, diallyl trisulphides or S-allyl-Cysteine), found in large quantities in fresh garlic [60,64,77], the profile of which changes significantly during long-lasting heat treatment of black garlic [108-110]. Fresh, undamaged garlic in the form of heads or cloves lacks a characteristic sharp, garlic smell and taste as long as its tissue structure remains intact $[13,14]$. According to the literature, colourless and odourless organosulphurics, such as alliin and $\gamma$-glutamyl-S-allyl-cysteine, naturally collected during fresh garlic storage, can account 
for $1.8 \%$ and $0.9 \%$ of its mass, respectively, and are precursors of the organosulphurics deciding of taste and smell characteristic of garlic [14]. Only mechanical damage to the structure, such as crushing, cutting, biting or heat treatment, causes the release of a vacuolar enzyme (allinase), hydrolysing alliin to unstable aromatic allicin (diallyl thiosulphonate), immediately decomposed into sulphides, disulphides and trisulphides of diallyl, and ajoenes [110]. At the same time, $\gamma$-glutamyl-s-allyl-cysteine present in garlic is converted into other metabolites, such as s-allylcysteine, which is assigned a number of valuable properties, including antioxidant properties $[13,14,24,60,71]$. As a result, consumption of fresh raw garlic is accompanied by a characteristic sharp and typically garlic aroma and taste. According to the studies by other authors, during the aging process of garlic, the profile of organosulphuric metabolites changes significantly with regard to their share and mutual proportions. Allicin, unstable at high temperatures and responsible for the sharp, typical taste of garlic, is converted into other organosulphuric metabolites, giving black garlic the unique taste and aroma [110]. The content of volatile compounds responsible for the unpleasant taste and aroma of garlic is significantly reduced. In addition, other metabolites (not detected in fresh garlic) are formed, in particular furfural derivatives, such as 2-acetylfuran or 5-methylfurfural, which contribute to the characteristic sweet taste of black garlic and eliminate its sharp and unpleasant taste [108-110]. In the literature the increase in the antioxidant capacity of black garlic is also explained by the increasing level of the Maillard reactions products formed during the heat treatment process. These products determine the characteristic black colour of garlic $[68,78,79,95,111,112]$.

Therefore, in this study an instrumental measurements of the colour of white (unprocessed) and black garlic from both conventional and organic cultivation systems were performed. Colour parameters in $L^{*} a^{*} b^{*}$ and RGB space obtained using the instrumental method ("electronic eye") in white and black, conventional and organic garlic are shown in Table 3.

Table 3. Colour parameters in $L^{*} a^{*} b^{*}$ and RGB space obtained using the instrumental method ("electronic eye") in white and black, conventional and organic garlic.

\begin{tabular}{ccccc}
\hline Colour Parameters & G & EG & BG & EBG \\
\hline $\begin{array}{c}L^{*} \text { (lightness) the line } \\
\text { should be 1/2pt, not 1pt }\end{array}$ & $83.85 \pm 0.31^{\mathrm{d}}$ & $81.25 \pm 2.04^{\mathrm{c}}$ & $25.42 \pm 0.03^{\mathrm{b}}$ & $18.92 \pm 1.03^{\mathrm{a}}$ \\
\hline$a^{*}$ (redness) & $3.52 \pm 0.36^{\mathrm{a}}$ & $3.58 \pm 0.05^{\mathrm{a}}$ & $6.15 \pm 0.71^{\mathrm{b}}$ & $6.26 \pm 0.08^{\mathrm{b}}$ \\
\hline$b^{*}$ (yellowness) & $6.43 \pm 0.12^{\mathrm{c}}$ & $7.36 \pm 0.88^{\mathrm{c}}$ & $5.04 \pm 0.89^{\mathrm{b}}$ & $2.86 \pm 0.02^{\mathrm{a}}$ \\
\hline R (redness) & $219.72 \pm 1.59^{\mathrm{c}}$ & $213.05 \pm 6.13^{\mathrm{c}}$ & $69.84 \pm 4.52^{\mathrm{b}}$ & $58.52 \pm 4.86^{\mathrm{a}}$ \\
\hline G (greenness) & $206.64 \pm 0.61^{\mathrm{d}}$ & $199.41 \pm 5.61^{\mathrm{c}}$ & $57.38 \pm 1.10^{\mathrm{b}}$ & $42.60 \pm 2.20^{\mathrm{a}}$ \\
\hline B (blueness) & $197.19 \pm 0.63^{\mathrm{c}}$ & $188.32 \pm 3.92^{\mathrm{c}}$ & $52.13 \pm 8.08^{\mathrm{b}}$ & $42.91 \pm 3.02^{\mathrm{a}}$ \\
\hline
\end{tabular}

Values are means \pm standard deviation $(\mathrm{n}=3){ }^{\mathrm{a}-\mathrm{d} \text { - }}$-different letters in the same line are significantly different (Duncan's test, $p<0.05$ ). G—conventional white garlic; EG—organic white garlic; BG—conventional black garlic; EBG—organic black garlic.

Significant differences $(p<0.05)$ were found between the colour of both white and black garlic (subjected to long-term heat treatment), both organic and conventional. The samples differed in colour parameters taking into account both the $L^{*} a^{*} b^{*}$ and RGB colour space. When comparing the colour of white vs. black garlic samples, significant differences $(p<0.05)$ can be noticed, especially in the case of the $L^{*}$ parameter. The white garlic samples ( $83.85 \pm 0.31$ for $G$ and $82.25 \pm 2.04$ for EG samples) had much higher $L^{*}$ values, which means that the samples were much lighter than the black ones (25.42 \pm 0.03 for BG and $18.92 \pm 1.03$ for EBG samples). The $a^{*}$ and $b^{*}$ colour parameters in the $L^{*} a^{*} b^{*}$ system, referring to the tones of red and yellow were characterised with significant differences $(p<0.05)$ in white and black garlic samples. The $b^{*}$ parameter values determined for white garlic samples $(6.43 \pm 0.12$ and $7.36 \pm 0.88$ respectively for conventional and organic samples) were also significantly $(p<0.05)$ higher compared to black one $(5.04 \pm 0.89$ 
and $2.86 \pm 0.02$, respectively, for conventional and organic samples), which means the white garlic samples had a greater colour shift towards yellow. The values of parameter $a^{*}$ determined for black garlic (about 6.20 for G and EG samples) were significant $(p<0.05)$ higher compared to the white one (about 3.5).

Considering the RGB colour model, it can be seen that white garlic exhibited higher $\mathrm{R}$ values (about 213-220) compared to black one (69.84 \pm 4.52 for BG sample and $58.52 \pm 4.86$ for EBG one), indicating that it was more saturated with red. For the colour parameter $G$, significantly higher values (about 203) were found for white than black garlic (57.38 \pm 1.10 for BG sample and $42.60 \pm 2.20$ for EBG one), which indicates that it was more saturated with green. A similar relationship was noted for the colour parameter $G$, which meant that fresh (white) garlic (197.19 \pm 0.63 and $188.32 \pm 3.92$ respectively for conventional and organic samples) showed a greater shift towards the blue colour than black garlic (52.13 \pm 8.08 and $42.91 \pm 3.02$ for respectively BG and EBG samples).

Our results are similar to those obtained by other authors. Choi et al. (2014) [73] showed that during long-term heat treatment $\left(35\right.$ days, temperature $70{ }^{\circ} \mathrm{C}$, relative humidity $90 \%$ ), the garlic changed its colour to dark brown. The values of the $\mathrm{L}^{*}$ and $\mathrm{b}^{*}$ parameters dropped dramatically (respectively from $68.44 \pm 1.66$ to $4.33 \pm 2.02$ and from $26.59 \pm 1.76$ to $-3.86 \pm 1.49$ ), and the value of the parameter $a^{*}$ increased (from $-3.84 \pm 0.46$ to $2.73 \pm 1.01)$. Other studies, on white and black garlic extracts showed a significant decrease in the value of $L^{*}$ parameter (from $39.65 \pm 3.98$ to $24.70 \pm 4.56$ ) and $b^{*}$ parameter (from $10.86 \pm 2.75$ to $1.47 \pm 2.75$ ) and increase in the value of $a^{*}$ parameter (from $-0.53 \pm 0.18$ to $4.35 \pm 1.68$ ) [113]. There is very little in the available literature regarding a detailed comparative analysis of the colour of white and black garlic. The research concerns mainly the intensity of browning ( $\Delta L^{*}$ parameter) of garlic during heat treatment processes. In terms of this parameter our results are similar to those of other authors $[60,68,69,71,73]$.

Changes in the colour of garlic during long-term heat treatment are explained in the literature by the production of dark substances during this process, i.e., melanoidins, responsible for the dark brown, even black colour of black garlic [8]. Melanoidins are formed in the late stages of the Maillard reaction from sugars and amino acids [114], as polymers, polycondensation products of fructans and/or pyrroles [115]. The speed and intensity of browning garlic during long-term heat treatment is closely related to temperature, relative humidity and processing time [116]. Maillard reactions are faster at higher temperatures, so an increase in temperature accelerates and intensifies the browning processes of black garlic $[68,69]$. Conversely, the higher relative humidity during the aging processes of garlic causes the slower rate and intensity of black garlic browning [64]. Additionally, along with extending the heat treatment time, the browning intensity of black garlic also increases [71].

Additionally, our research showed significant $(p<0.05)$ differences in colour parameters between conventional and organic garlic, both in the case of white and black garlic subjected to long-term heat treatment (45 days, temperature $70{ }^{\circ} \mathrm{C}$ and relative humidity $80 \%$ ). Detailed colour analysis of white and black garlic from conventional and organic cultivation using the instrumental method ("electronic eye") are presented in Figures 2-5. 


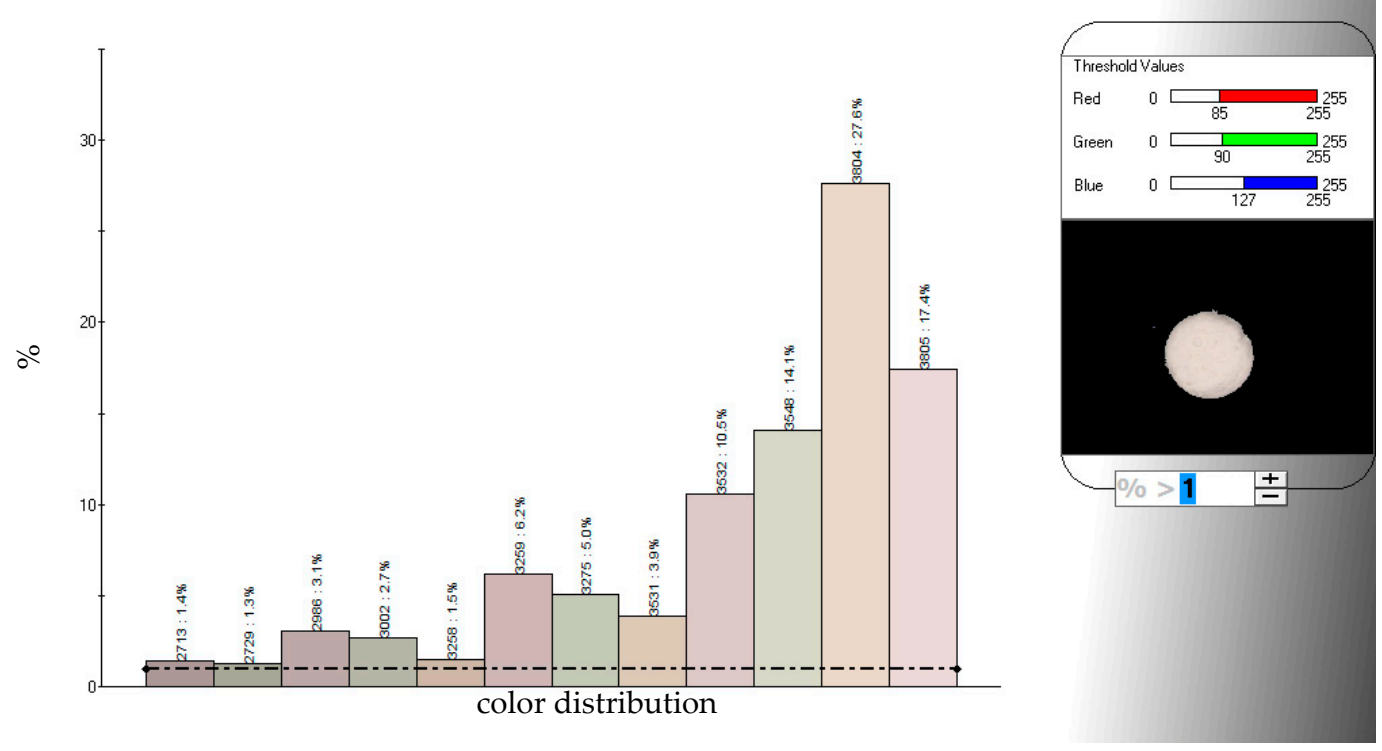

Figure 2. Detailed colour analysis of white garlic from conventional cultivation $(\mathrm{G})$ using the instrumental method ("electronic eye").
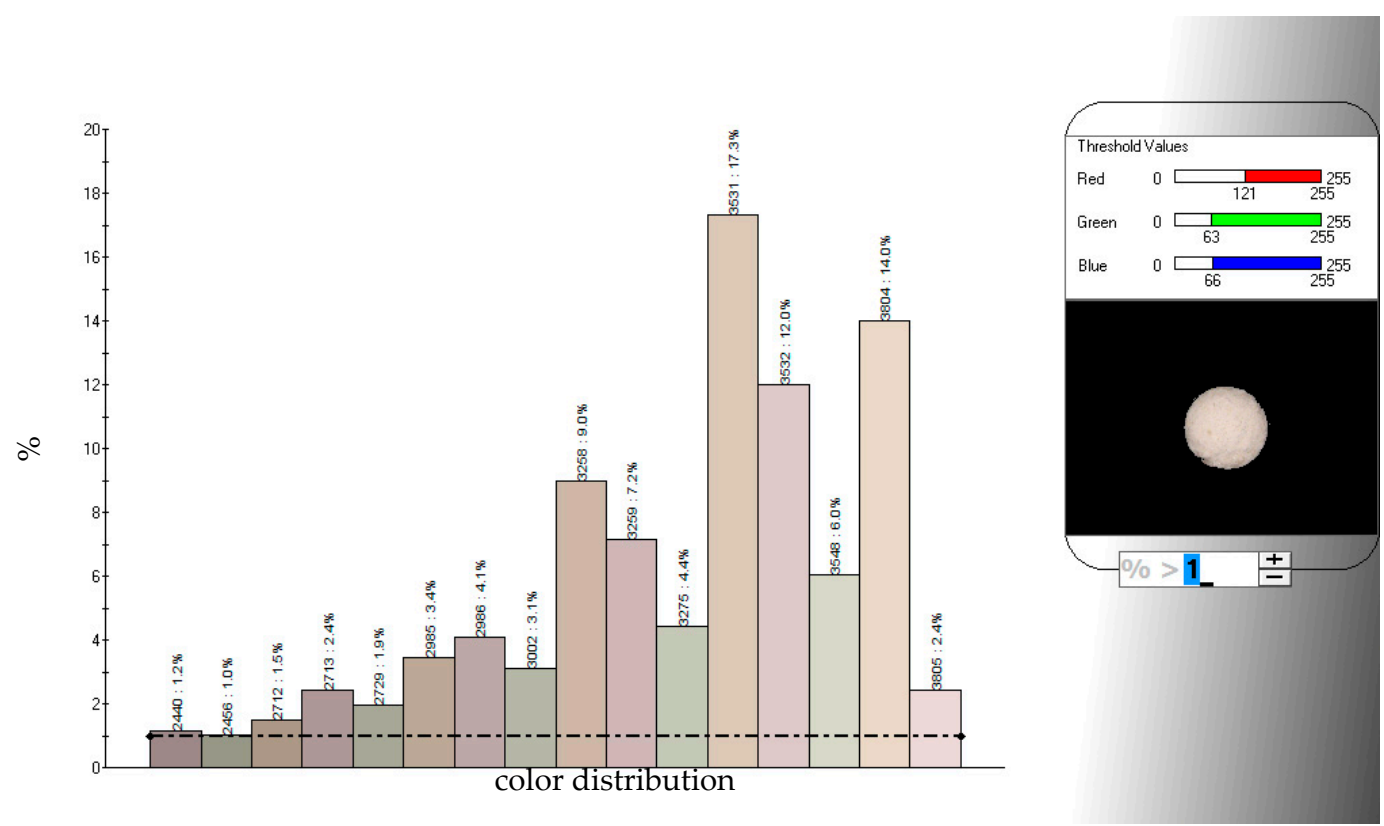

Figure 3. Detailed colour analysis of white garlic from organic cultivation (EG) using the instrumental method ("electronic eye"). 

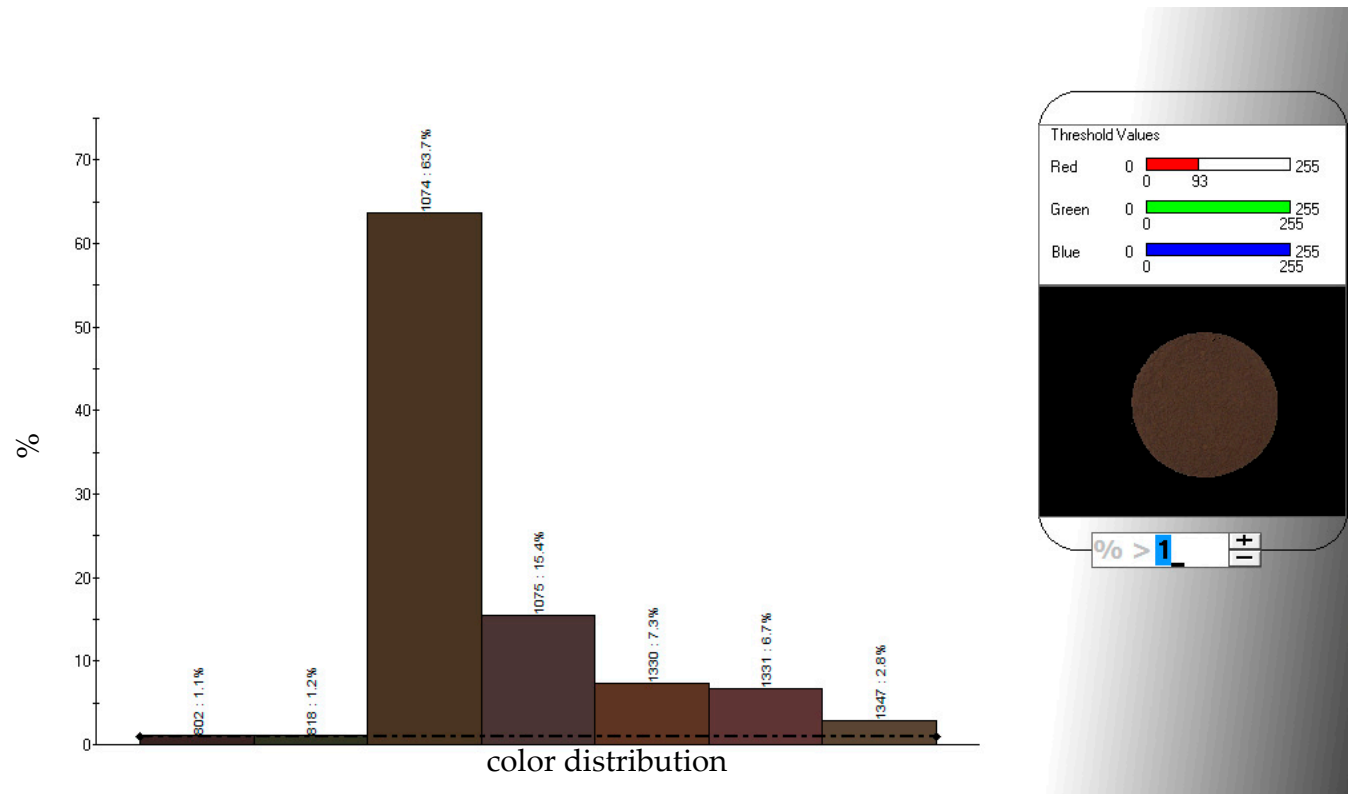

Figure 4. Detailed colour analysis of black garlic from conventional cultivation (BG) using the instrumental method ("electronic eye").
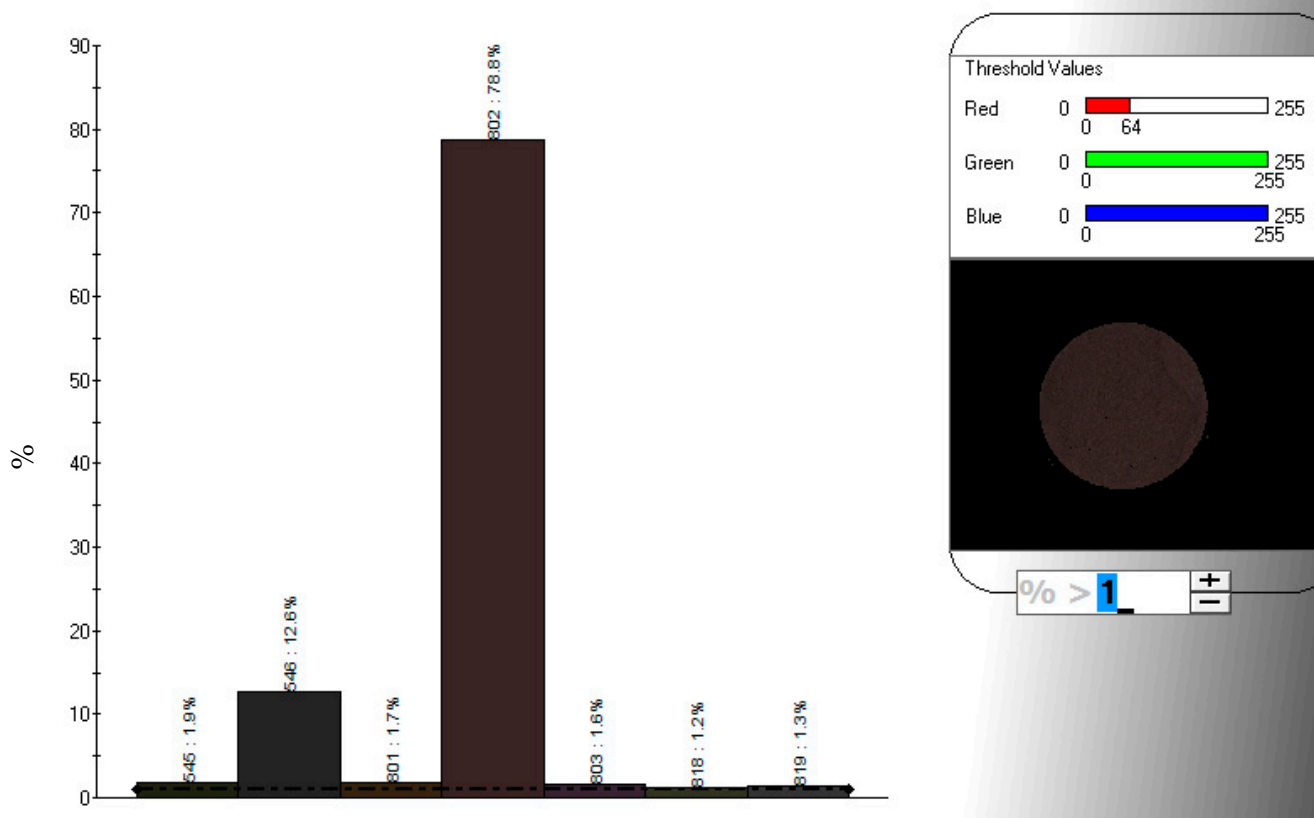

color distribution

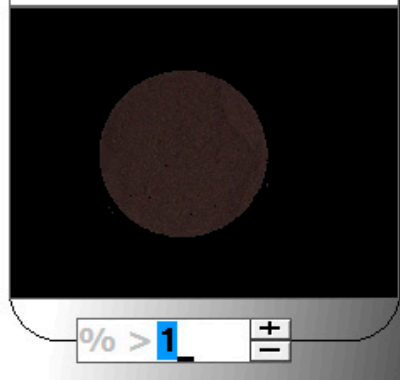

Figure 5. Detailed colour analysis of black garlic from organic cultivation (EBG) using the instrumental method ("electronic eye").

In the $L^{*} a^{*} b^{*}$ space, these differences mainly concerned the $L^{*}$ colour parameter. White conventional garlic had a significantly higher value of the $L^{*}$ parameter than organic garlic, which means that sample G was lighter than EG. On the other hand, the EBG sample had significantly greater intensity of browning than garlic from conventional cultivation, because the $L^{*}$ parameter value was much lower for EBG, so it was characterized by a significantly darker colour. For white conventional and organic garlic no major differences 
were found in the $a^{*}$ and $b^{*}$ colour parameters (on average $3.55 \pm 0.04$ and $6.90 \pm 0.66$, respectively), in other words these samples were characterized by a similar shade of red and yellow. However, significant differences for these parameters were found in black garlic. The $a^{*}$ parameter value determined for garlic EBG was higher compared to BG, which means that EBG garlic had a greater redness than BG. On the other hand, for the $b^{*}$ colour parameter, a higher value was found in garlic BG than in EBG, which means that garlic from conventional cultivation had a greater shift towards the yellow. In the RGB colour space, no significant differences were found between white conventional and organic garlic in terms of the $\mathrm{R}$ and $\mathrm{B}$ colour parameters, so these samples had a similar intensity of red and blue colour. However, significant differences were found for the colour parameter G. Conventional garlic was characterized by a higher colour parameter $G$ than organic, which means that it was more saturated with green. In the case of black garlic, all colour parameters in the RGB space were significantly $(p<0.05)$ higher in conventional than organic garlic (by approx. 19.3\%, 34.7\% and 21.5\% for the R, G and B parameters, respectively), which means that conventional black garlic (BG) was characterized by a greater saturation of red, green and blue colour than EBG. No comparative data has been found in the literature for either white or black garlic from conventional and organic cultivation. Significant differences in the colour of the white and black garlic samples tested prove that the applied processes of long-term heat treatment have a great influence on the appearance of garlic. It can be concluded that, as a result of this process, a new product with significantly changed characteristics is created.

\section{Conclusions}

During the process of long-term heat treatment, a number of changes occur in black garlic, resulting in a product with completely different physicochemical characteristics as compared to fresh garlic. Black garlic has a dark brown to black colour, a more sticky, jelly-like consistency and also completely loses the typical sharp taste and aroma of white (fresh) garlic, gaining a sweet and sour taste. The processes of producing black garlic are also accompanied by changes in the content and proportions of bioactive ingredients, such as organosulphur compounds, polyphenols, organic acids or reducing sugars resulting from the decomposition of polysaccharides or produced during the Maillard reactions. Our studies have shown a significantly higher content of total soluble solids ( ${ }^{\circ}$ Brix) and total reducing sugars in black garlic compared to unprocessed white, which means that as a result of the aging process used, the sum of free reducing sugars increased more than 3.5 times, and a significantly higher content of these components was found in organic black garlic than in conventional black garlic. The applied heat treatment of garlic caused a significant increase in the content of bioactive ingredients and antioxidant activity in black garlic as compared to white (unprocessed) garlic, with the differences being greater in black garlic from organic cultivation. Total polyphenols, phenolic acids, flavonoids and antioxidant activity of black garlic were significantly higher in black than in white garlic, with the highest content of these ingredients and the highest antioxidant activity found in organic black garlic and they were significantly higher than in black garlic from conventional cultivation.

All organic garlic samples had improved bioactive ingredients and antioxidant activity compared to conventional garlic for both white and heat-treated black garlic. The production of black garlic, especially organic, allows to obtain a product with higher amount of bioactive compounds, which can be widely used in the design of health-promoting functional food. Therefore, the results of our research are important both for consumers who show an increasing interest in health-promoting foods, and for producers of food with high nutritional, dietary and pro-health values. Therefore, comparative studies of physicochemical and health-promoting properties are important for many industries and the food market. Further research is necessary to select the most optimal technological processes and conditions of their course, in order to obtain products with the best pro-health, dietary and nutritional values. 
Author Contributions: Conceptualization: K.N. and A.S.; methodology: K.N. and E.H.; software: K.N.; validation: K.N., A.S. and E.H.; formal analysis: K.N.; investigation: K.N.; resources: K.N.; data curation: K.N.; writing—original draft preparation: K.N.; writing—review and editing: K.N.; visualization: K.N.; supervision: K.N.; project administration: K.N.; funding acquisition: K.N. All authors have read and agreed to the published version of the manuscript.

Funding: This research received no external funding.

Conflicts of Interest: The authors declare no conflict of interest.

\section{References}

1. Butt, M.S.; Sultan, M.T.; Iqbal, J. Garlic: Nature's protection against physiological threats. Crit. Rev. Food Sci. Nutr. 2009, 49, 538-551. [CrossRef]

2. Tripathi, K.A. Garlic, the spice of life, Part 1. Review. Asian J. Res. Chem. 2009, 2, 8-13.

3. Bayan, L.; Koulivand, P.H.; Gorji, A. Garlic: A review of potential therapeutic effects. Avicenna J. Phytomed. 2014, 4, 1-14. [CrossRef] [PubMed]

4. Santhosha, S.G.; Prakash, J.; Prabhavathi, S.N. Bioactive components of garlic and their physiological role in health maintenance: A review. Food Biosci. 2013, 3, 59-74. [CrossRef]

5. Martins, N.; Petropoulos, S.; Ferreira, I.C.F.R. Chemical composition and bioactive compounds of garlic (Allium sativum L.) as affected by pre- and post-harvest conditions: A review. Food Chem. 2016, 211, 41-50. [CrossRef]

6. Szychowski, K.A.; Rybczyńska-Tkaczyk, K.; Gaweł-Bęben, K.; Świeca, M.; Karaś, M.; Jakubczyk, A.; Matysiak, M.; Binduga, U.E.; Gmiński, J. Characterization of active compounds of different garlic (Allium sativum L.) cultivars. Polish J. Food Nutr. Sci. 2018, 68, 73-81. [CrossRef]

7. Nutritive Value of Foods. In Agricultural Research Service. Food Data Central ("Garlic, Raw"); United States Department of Agriculture (USDA): Washington, DC, USA, 2008; Home and Garden Bulletin Number 72.

8. Qiu, Z.; Zheng, Z.; Zhang, B.; Sun-Waterhouse, D.; Qiao, X. Formation, nutritional value, and enhancement of characteristic components in black garlic: A review for maximizing the goodness to humans. Compr. Rev. Food Sci. Food Saf. 2020, 19, 801-834. [CrossRef]

9. Shang, A.; Cao, S.Y.; Xu, X.Y.; Gan, R.Y.; Tang, G.Y.; Corke, H.; Mavumengwana, V.; Li, H.B. Bioactive compounds and biological functions of garlic (Allium sativum L.). Foods 2019, 8, 246. [CrossRef]

10. Gorinstein, S.; Drzewiecki, J.; Leontowicz, H.; Leontowicz, M.; Najman, K.; Jastrzębski, Z.; Zachwieja, Z.; Barton, H.; Shtabsky, B.; Katrich, E.; et al. Comparison of the bioactive compounds and antioxidant potentials of fresh and cooked polish, ukrainian and izraeli gralic. J. Agric. Food Chem. 2005, 53, 2726-2732. [CrossRef]

11. Gorinstein, S.; Jastrzębski, Z.; Leontowicz, H.; Leontowicz, M.; Namiesnik, J.; Najman, K.; Park, Y.S.; Heo, B.G.; Cho, J.Y.; Bae, J.H. Comparative control of the bioactivity of some frequently consumed vegetables subjected to different processing conditions. Food Control 2009, 20, 407-413. [CrossRef]

12. Rivlin, R.S.; Budoff, M.; Amagase, H. Significance of garlic and its constituents in cancer and cardiovascular disease. J. Nutr. 2006, 136, 736-740. [CrossRef]

13. Amagase, H.; Petesch, B.L.; Matsuura, H.; Kasuga, S.; Itakura, Y. Intake of garlic and its bioactive compounds. J. Nutr. 2001, 131, 955-962. [CrossRef] [PubMed]

14. Amagase, H. Clarifying the real bioactive constituents of garlic. J. Nutr. 2006, 136, 716-725. [CrossRef] [PubMed]

15. Lawal, B.; Shittu, O.K.; Oibiokpa, F.I.; Mohammed, H.; Umar, S.I.; Haruna, G.M. Antimicrobial evaluation, acute and sub-acute toxicity studies of Allium sativum. J. Acute Dis. 2016, 5, 296-301. [CrossRef]

16. Guo, Y.J. Experimental study on the optimization of extraction process of garlic oil and its antibacterial effects. Afr. J. Tradit. Complement. Altern. Med. 2014, 11, 411-414. [CrossRef] [PubMed]

17. Liu, Q.; Meng, X.; Li, Y.; Zhao, C.N.; Tang, G.Y.; Li, H.B. Antibacterial and antifungal activities of spices. Int. J. Mol. Sci. 2017, 18, 1283. [CrossRef]

18. Fratianni, F.; Riccardi, R.; Spigno, P.; Ombra, M.N.; Cozzolino, A.; Tremonte, P.; Coppola, R.; Nazzaro, F. Biochemical characterization and antimicrobial and antifungal activity of two endemic varieties of garlic (Allium sativum L.) of the campania region, southern Italy. J. Med. Food. 2016, 19, 686-691. [CrossRef]

19. Li, W.R.; Shi, Q.S.; Liang, Q.; Huang, X.M.; Chen, Y.B. Antifungal effect and mechanism of garlic oil on Penicillium funiculosum. Appl. Microbiol. Biot. 2014, 98, 8337-8346. [CrossRef]

20. Li, W.R.; Shi, Q.S.; Dai, H.Q.; Liang, Q.; Xie, X.B.; Huang, X.M.; Zhao, G.Z.; Zhang, L.X. Antifungal activity, kinetics and molecular mechanism of action of garlic oil against Candida albicans. Sci. Rep. 2016, 7, 22805. [CrossRef]

21. Pittler, M.H.; Ernest, E. Clinical effectiveness of garlic (Allium sativum). Mol. Nutr. Food Res. 2007, 51, 1382-1385. [CrossRef]

22. Londhe, V.; Gavasane, A.; Nipate, S.; Bandawane, D.; Chaudhari, P. Role of garlic (Allium sativum) in various diseases: An overview. J. Pharm. Res. Opin. 2011, 1, 129-134.

23. Yun, H.M.; Ban, J.O.; Park, K.R.; Lee, C.K.; Jeong, H.S.; Han, S.B.; Hong, J.T. Potential therapeutic effects of functionally active compounds isolated from garlic. Pharm. Ther. 2014, 142, 183-195. [CrossRef] [PubMed] 
24. Corzo-Martinez, M.; Corso, N.; Villamiel, M. Biological properties of onions and garlic. Trends Food Sci. Technol. 2007, 18, 609-625. [CrossRef]

25. Zardast, M.; Namakin, K.; Kaho, J.E.; Hashemi, S.S. Assessment of antibacterial effect of garlic in patients infected with Helicobacter pylori using urease breath test. Avicenna J. Phytomed. 2016, 6, 495-501.

26. Chen, Y.A.; Tsai, J.C.; Cheng, K.C.; Liu, K.F.; Chang, C.K.; Hsieh, C.W. Extracts of black garlic exhibits gastrointestinal motility effect. Food Res. Int. 2018, 107, 102-109. [CrossRef]

27. El-Ashmawy, N.E.; Khedr, E.G.; El-Bahrawy, H.A.; Selim, H.M. Gastroprotective effect of garlic in indomethacin induced gastric ulcer in rats. Nutrition 2016, 32, 849-854. [CrossRef]

28. Shukla, Y.; Kalra, N. Cancer chemoprevention with garlic and its constituents. Cancer Lett. 2007, 247, 167-181. [CrossRef]

29. Wink, D.A.; Hines, H.B.; Cheng, R.Y.; Switzer, C.H.; Flores-Santana, W.; Vitek, M.P.; Ridnour, L.A.; Colton, C.A. Nitric oxide and redox mechanisms in the immune response. J. Leukoc. Biol. 2011, 89, 873-891. [CrossRef]

30. Takashima, M.; Kanamori, Y.; Kodera, Y.; Morihara, N.; Tamura, K. Aged garlic extract exerts endothelium-dependent vasorelaxant effect on rat aorta by increasing nitric oxide production. Phytomedicine 2017, 15, 56-61. [CrossRef]

31. Ushijima, M.; Takashima, M.; Kunimura, K.; Kodera, Y.; Morihara, N.; Tamura, K. Effects of S-1-propenylcysteine, a sulfur compound in aged garlic extract, on blood pressure and peripheral circulation in spontaneously hypertensive rats. J. Pharm. Pharmacol. 2018, 70, 559-565. [CrossRef]

32. Park, B.M.; Cha, S.A.; Kim, H.Y.; Kang, D.K.; Yuan, K.; Chun, H.; Chae, S.W.; Kim, S.H. Fermented garlic extract decreases blood pressure through nitrite and sGC-cGMP-PKG pathway in spontaneously hypertensive rats. J. Funct. Foods 2016, 22, 156-165. [CrossRef]

33. Gorinstein, S.; Drzewiecki, J.; Leontowicz, H.; Leontowicz, M.; Najman, K.; Katrich, E.; Barasch, D.; Yamamoto, K.; Trakhtenberg, S. Raw and boiled garlic enhances plasma antioxidant activity and improves plasma lipid metabolism in cholesterol-fed rats. Life Sci. 2006, 78, 655-663. [CrossRef]

34. Gorinstein, S.; Leontowicz, M.; Leontowicz, H.; Najman, K.; Namiesnik, J.; Park, Y.S.; Jung, S.T.; Kang, S.G.; Trakhtenberg, S. Supplementation of garlic lowers lipids and increases antioxidant capacity in plasma of rats. Nutr. Res. 2006, 26, 362-368. [CrossRef]

35. Gorinstein, S.; Leontowicz, H.; Leontowicz, M.; Jastrzębski, Z.; Najman, K.; Tashma, Z.; Katrich, E.; Heo, B.G.; Cho, J.Y.; Park, Y.J.; et al. The influence of raw and processed garlic and onions on plasma classical and non-classical atherosclerosis indices: Investigations in vitro and in vivo. Phytother. Res. 2010, 24, 706-714. [CrossRef] [PubMed]

36. Albrakati, A.Y. Protective effect of garlic against diabetic retinopathy in adult albino rats. Res. J. Pharm. Biol. Chem. Sci. 2016, 7, 2748-2759.

37. Wang, J.; Zhang, X.M.; Lan, H.L.; Wang, W.J. Effect of garlic supplement in the management of type 2 diabetes mellitus (T2DM): A meta-analysis of randomized controlled trials. Food Nutr. Res. 2017, 61, 1377571. [CrossRef]

38. Yang, C.; Li, L.H.; Yang, L.G.; Lu, H.; Wang, S.K.; Sun, G.J. Anti-obesity and hypolipidemic effects of garlic oil and onion oil in rats fed a high-fat diet. Nutr. Metab. 2018, 15, 43. [CrossRef]

39. Bard, G.M.; Arafa, N.S. Synergetic effect of aged garlic extract and methotrexate on rheumatoid arthritis induced by collagen in male albino rats. Indian J. Exp. Biol. 2020, 58, 33-38.

40. Bagul, M.; Kakumanu, S.; Wilson, T.A. Crude garlic extract inhibits cell proliferation and induces cell cycle arrest and apoptosis of cancer cells in vitro. J. Med. Food 2015, 18, 731-737. [CrossRef]

41. Shin, S.S.; Song, J.H.; Hwang, B.; Noh, D.H.; Park, S.L.; Kim, W.T.; Park, S.S.; Kim, W.J.; Moon, S.K. HSPA6 augments garlic extractinduced inhibition of proliferation, migration, and invasion of bladder cancer EJ cells; implication for cell cycle dysregulation, signaling pathway alteration, and transcription factor-associated mmp-9 regulation. PLoS ONE 2017, 12, e0171860. [CrossRef]

42. Jiang, X.Y.; Zhu, X.S.; Huang, W.Z.; Xu, H.Y.; Zhao, Z.X.; Li, S.Y.; Li, S.Z.; Cai, J.H.; Cao, J.M. Garlic-derived organosulfur compound exerts antitumor efficacy via activation of MAPK pathway and modulation of cytokines in SGC-7901 tumor-bearing mice. Int. Immunopharmacol. 2017, 48, 135-145. [CrossRef] [PubMed]

43. Petrovic, V.; Nepal, A.; Olaisen, C.; Bachke, S.; Hira, J.; Sogaard, C.K.; Rost, L.M.; Misund, K.; Andreassen, T.; Melo, T.M.; et al. Anti-cancer potential of homemade fresh garlic extract is related to increased endoplasmic reticulum stress. Nutrients 2018, 10, 450. [CrossRef] [PubMed]

44. Wei, Z.H.; Shan, Y.L.; Tao, L.; Liu, Y.P.; Zhu, Z.J.; Liu, Z.G.; Wu, Y.Y.; Chen, W.X.; Wang, A.Y.; Lu, Y. Diallyl trisulfides, a natural histone deacetylase inhibitor, attenuate HIF-1 synthesis, and decreases breast cancer metastasis. Mol. Carcinog. 2017, 56, 2317-2331. [CrossRef] [PubMed]

45. Jang, H.J.; Lee, H.J.; Yoon, D.K.; Ji, D.S.; Kim, J.H.; Lee, C.H. Antioxidant and antimicrobial activities of fresh garlic and aged garlic by-products extracted with different solvents. Food Sci. Biotechnol. 2017, 27, 219-225. [CrossRef] [PubMed]

46. Im, M.H.; Park, Y.S.; Leontowicz, H.; Leontowicz, M.; Namiesnik, J.; Ham, K.S.; Kang, S.G.; Najman, K.; Gorinstein, S. The thermostability, bioactive compounds and antioxidant activity of some vegetables subjected to different duration of boiling: Investigation in vito. LWT Food Sci. Technol. 2011, 44, 92-99. [CrossRef]

47. Gorinstein, S.; Leontowicz, H.; Leontowicz, M.; Namiesnik, J.; Najman, K.; Drzewiecki, J.; Cvikrova, M.; Martincova, O.; Katrich, E.; Trakhtenberg, S. Comparison of the main bioactive compounds and antioxidant activities in garlic and white and red onions after treatment protocols. J. Agric. Food Chem. 2008, 56, 4418-4426. [CrossRef]

48. Capasso, A. Antioxidant action and therapeutic efficacy of Allium sativum L. Molecules 2013, 18, 690-700. [CrossRef] 
49. Bozin, B.; Dukic, N.M.; Samojlik, I.; Goran, A.; Igic, R. Phenolics as antioxidants in garlic (Allium sativum L.). Food Chem. 2008, 111, 925-929. [CrossRef]

50. Arnault, I.; Auger, J. Seleno-compounds in garlic and onion. J. Chromatogr. A 2006, 1112, 23-30. [CrossRef]

51. Omar, S.H.; Al-Wabel, N.A. Organosulfur compounds and possible mechanism of garlic in cancer. Saudi Pharm. J. 2010, 18, 51-58. [CrossRef]

52. Ramirez, D.A.; Locatelli, D.A.; Gonzálezc, R.E.; Cavagnaro, P.F.; Alejandra, B.; Camargo, A.B. Analytical methods for bioactive sulfur compounds in Allium: An integrated review and future directions. J. Food Comp. Anal. 2017, 61, 4-19. [CrossRef]

53. Rice-Evans, C.; Miller, N.; Paganga, G. Antioxidant properties of phenolic compounds. Review. Trends Plant Sci. 1997, 2, 152-159. [CrossRef]

54. Chen, S.; Shen, X.; Cheng, S.; Li, P.; Du, J.; Chang, Y.; Meng, H. Evaluation of garlic cultivars for polyphenolic content and antioxidant properties. PLoS ONE 2013, 8, e79730. [CrossRef] [PubMed]

55. Kim, J.; Kang, O.J.; Gweon, O.C. Comparison of phenolic acids and flavonoids in black garlic at different thermal processing steps. J. Funct. Foods 2013, 5, 80-86. [CrossRef]

56. González, R.E.; Soto, V.C.; Sance, M.M.; Camargo, A.B.; Galmarini, C.R. Variability of solids, organosulfur compounds, pungency and health-enhancing traits in garlic (Allium sativum L.) cultivars belonging to different ecophysiological groups. J. Agric. Food Chem. 2009, 57, 10282-10288. [CrossRef]

57. Khar, A.; Banerjee, K.; Jadhav, M.R.; Lawande, K. Evaluation of garlic ecotypes for allicin and other allyl thiosulphinates. Food Chem. 2011, 128, 988-996. [CrossRef]

58. Randle, W.M.; Lancaster, J.; Shaw, M.; Sutton, K.; Hay, R.; Bussard, M. Quantifying onion flavor compounds responding to sulfur fertility-sulfur increases levels of alk(en)yl cysteine sulfoxides and biosynthetic intermediates. J. Am. Horticult. Sci. 1995, 120, 1075-1081. [CrossRef]

59. Ichikawa, M.; Ide, N.; Yoshida, J.; Yamaguchi, H.; Ono, K. Determination of seven organosulfur compounds in garlic by high-performance liquid chromatography. J. Agric. Food Chem. 2006, 54, 1535-1540. [CrossRef]

60. Kimura, S.; Tung, Y.C.; Pan, M.H.; Su, N.W.; Lai, Y.J.; Cheng, K.C. Black garlic: A critical review of its production, bioactivity, and application. J. Food Drug Anal. 2017, 25, 62-70. [CrossRef]

61. Kodera, Y.; Suzuki, A.; Imada, O.; Kasuga, S.; Sumioka, I.; Kanazawa, A.; Toru, N.; Fujikawa, M.; Nassage, S.; Masamoto, K.; et al. Physical, chemical and biological properties of S-allylcysteine, an amino acid derived from garlic. J. Agric. Food Chem. 2002, 50, 622-632. [CrossRef]

62. Hoshino, T.; Kashimoto, N.; Kasuga, S. Effects of garlic preparations on the gastrointestinal mucosa. J Nutr. 2001, 131, 1109-1113. [CrossRef] [PubMed]

63. Ryu, J.H.; Kang, D. Physicochemical properties, biological activity, health benefits, and general limitations of aged black garlic: A review. Molecules 2017, 22, 919. [CrossRef]

64. Bae, S.E.; Cho, S.Y.; Won, Y.D.; Lee, S.H.; Park, H.J. Changes in S-allyl cysteine contents and physicochemical properties of black garlic during heat treatment. LWT Food Sci. Technol. 2014, 55, 397-402. [CrossRef]

65. Locatelli, D.A.; Altamirano, J.C.; González, R.E.; Camargo, A.B. Home-cooked garlic remains a healthy food. J. Funct. Foods 2015, 16, 1-8. [CrossRef]

66. Im, M.H.; Park, Y.S.; Ham, K.S.; Kang, S.G.; Heo, B.G.; Leontowicz, H.; Leontowicz, M.; Namiesnik, J.; Najman, K.; Gorinstein, S. Effects of cooking on the bioactivity of locus roots and white onions. Int. J. Food Prop. 2012, 15, 49-59. [CrossRef]

67. Yuan, H.; Sun, L.; Chen, M.; Wang, J. An analysis of the changes on intermediate products during the thermal processing of black garlic. Food Chem. 2018, 239, 56-61. [CrossRef]

68. Toledano-Medina, M.A.; Pérez-Aparicio, J.; Moreno-Rojas, R.; Merinas-Amo, T. Evolution of some physicochemical and antioxidant properties of black garlic whole bulbs and peeled cloves. Food Chem. 2016, 199, 135-139. [CrossRef]

69. Toledano-Medina, M.A.; Merinas-Amo, T.; Fernández-Bedmar, Z.; Rafael Font, R.; Del Río-Celestino, M.; Pérez-Aparicio, J.; Moreno-Ortega, A.; Alonso-Moraga, Á.; Moreno-Rojas, R. Physicochemical characterization and biological activities of black and white garlic: In vivo and in vitro assays. Foods 2019, 8, 220. [CrossRef]

70. Zhang, X.; Li, N.; Lu, X.; Liu, P.; Qiao, X. Effects of temperature on the quality of black garlic. J. Sci. Food Agric. 2016, 96, 2366-2372. [CrossRef]

71. Zhang, Z.; Lei, M.; Liu, R.; Gao, Y.; Xu, M.; Zhang, M. Evaluation of alliin, saccharide contents and antioxidant activities of black garlic during thermal processing. J. Food Biochem. 2015, 39, 39-47. [CrossRef]

72. Choi, D.J.; Lee, S.J.; Kang, M.J.; Cho, H.S.; Sung, N.J.; Shin, J.H. Physicochemical characteristics of black garlic (Allium sativum L.). J. Korean Soc. Food Sci. Nutr. 2008, 37, 465-471. [CrossRef]

73. Choi, I.S.; Cha, H.S.; Lee, Y.S. Physicochemical and antioxidant properties of black garlic. Molecules 2014, 19, 16811-16823. [CrossRef] [PubMed]

74. Martínez-Casas, L.; Lage-Yusty, M.; López-Hernández, J. Changes in the aromatic profile, sugars and bioactive compounds when purple garlic is transformed into black garlic. J. Agric. Food Chem. 2017, 65, 10804-10811. [CrossRef] [PubMed]

75. Cheong, K.L.; Yan, F.; Huang, X. Enzymologic characterization of garlic fructan exohydrolase. J. Food Biochem. 2012, 36, $248-253$. [CrossRef]

76. Lu, X.; Li, N.; Qiao, X.; Qiu, Z.; Liu, P. Effects of thermal treatment on polysaccharide degradation during black garlic processing. LWT Food Sci. Technol. 2018, 95, 223-229. [CrossRef] 
77. Shin, J.H.; Choi, D.J.; Chung, M.J.; Kang, M.J.; Sung, N.J. Changes of physicochemical components and antioxidant of aged garlic at different temperatures. J. Korean Soc. Food Sci. Nutr. 2008, 37, 1174-1181. [CrossRef]

78. Hwang, I.G.; Kim, H.Y.; Woo, K.S.; Lee, J.; Jeong, H.S. Biological activities of Maillard reaction products (MRPs) in a sugar-amino acid model system. J. Food Chem. 2011, 126, 221-227. [CrossRef]

79. Yuan, H.; Sun, L.; Chen, M.; Wang, J. The comparison of the contents of sugar, Amadori, and Heyns compounds in fresh and black garlic. J. Food Sci. 2016, 81, 1662-1668. [CrossRef] [PubMed]

80. Liang, T.; Wei, F.; Lu, Y.; Kodani, Y.; Nakada, M.; Miyakawa, T.; Tanokura, M. Comprehensive NMR analysis of compositional changes of black garlic during thermal processing. J. Agric. Food Chem. 2015, 63, 683-691. [CrossRef]

81. Kang, O.J. Physicochemical characteristics of black garlic after different thermal processing steps. Prev. Nutr. Food Sci. 2016, 21, 348-354. [CrossRef]

82. Lu, X.; Li, N.; Qiao, X.; Qiu, Z.; Liu, P. Composition analysis and antioxidant properties of black garlic extract. J. Food Drug Anal. 2017, 25, 340-349. [CrossRef] [PubMed]

83. Lee, Y.M.; Gweon, O.C.; Seo, Y.J.; Im, J.; Kang, M.J.; Kim, M.J.; Kim, J.I. Antioxidant effect of garlic and aged black garlic in animal model of type 2 diabetes mellitus. Nutr. Res. Pract. 2009, 3, 156-161. [CrossRef] [PubMed]

84. Beato, V.M.; Orgaz, F.; Mansilla, F.; Montaño, A. Changes in phenolic compounds in garlic (Allium sativum L.) owing to the cultivar and location of growth. Plant Foods Hum. Nutr. 2011, 66, 218-223. [CrossRef] [PubMed]

85. AOAC. International Official Methods of Analysis, 18th ed.; Association of Official Analytical Chemists: Washington, DC, USA, 2000.

86. Ponder, A.; Hallman, E. The nutritional value and vitamin C content of different raspberry cultivars from organic and conventional production. J. Food Compos. Anal. 2020, 87, 103429. [CrossRef]

87. Hallmann, E.; Kazimierczak, R.; Marszałek, K.; Drela, N.; Kiernozek, E.; Toomik, P.; Matt, D.; Luik, A.; Rembiałkowska, E. The nutritive value of organic and conventional white cabbage (Brassica oleracea L. var. capitata) and anti-apoptotic activity in gastric adenocarcinoma cells of sauerkraut juice produced therof. J. Agric. Food Chem. 2017, 65, 8171-8183. [CrossRef]

88. Singleton, V.L.; Rossi, J.A. Colorimetry of total phenolics with phosphomolybdic acid reagents. Am. J. Enol. Vitic. 1965, 16, 144-158.

89. Re, R.; Pellegrini, N.; Proteggente, A.; Pannala, A.; Yang, M.; Rice-Evans, C. Antioxidant activity applying an improved ABTS radical cation decolorization assay. Free Radic. Biol. Med. 1999, 26, 1231-1237. [CrossRef]

90. Najman, K.; Sadowska, A.; Hallmann, E. Influence of thermal processing on the bioactive, antioxidant, and physicochemical properties of conventional and organic agriculture black garlic (Allium sativum L.). Appl. Sci. 2020, 10, 8638. [CrossRef]

91. Sun, Y.E.; Wang, W. Changes in nutritional and bio-functional compounds and antioxidant capacity during black garlic processing. J. Food Sci. Technol. 2018, 55, 479-488. [CrossRef]

92. Petersson, K.; Nordlund, E.; Tornberg, E.; Eliasson, A.C.; Buchert, J. Impact of cell wall-degrading enzymes on water-holding capacity and solubility of dietary fibre in rye and wheat bran. J. Sci. Food Agric. 2013, 93, 882-889. [CrossRef]

93. Toledano-Medina, M.A.; Pérez-Aparicio, J.; Moreno-Ortega, A.; Moreno-Rojas, R. Influence of variety and storage time of fresh garlic on the physicochemical and antioxidant properties of black garlic. Foods 2019, 8, 314. [CrossRef] [PubMed]

94. Jung, I.; Sohn, H. Antioxidation, antimicrobial and antithrombosis activities of aged black garlic (Allium sativum L.). Korean J. Microbiol. Biotechnol. 2014, 3, 285-292. [CrossRef]

95. Yang, H. The properties and application of fructose syrup. Food Sci. 2002, 23, 154-156.

96. Li, N.Y.; Lu, X.M.; Pei, H.B.; Qiao, X.G. Effect of freezing pretreatment on the processing time and quality of black garlic. J. Food Process. Eng. 2015, 38, 329-335. [CrossRef]

97. Martins, S.I.F.S.; Jongen, W.M.F.; van Boekel, M.A.J.S. A review of Maillard reaction in food and implications to kinetic modelling. Trends Food Sci. Technol. 2000, 11, 364-375. [CrossRef]

98. Rahman, M.S. Handbook of Food Preservation, 2nd ed.; CRC Press: New York, NY, USA, 2007.

99. Blecker, C.; Fougnies, C.; van Herck, J.C.; Chevalier, J.P.; Paquot, M. Kinetic study of the acid hydrolysis of various oligofructose samples. J. Agric. Food Chem. 2002, 50, 1602-1607. [CrossRef]

100. Limacher, A.; Kerler, J.; Davidek, T.; Schmalzried, F.; Blank, I. Formation of furan and methylfuran by Maillard-type reactions in model systems and food. J. Agric. Food Chem. 2008, 56, 3639-3647. [CrossRef]

101. Huyghues-Despointes, A.; Yaylayan, V.A. Retro-aldol and redox reactions of Amadori compounds: Mechanistic studies with variously labeled D- $\left[{ }^{13} \mathrm{C}\right]$ glucose. J. Agric. Food Chem. 1996, 44, 672-681. [CrossRef]

102. Davidek, T.; Devaud, S.; Robert, F.; Blank, I. Sugar fragmentation in the Maillard reaction cascade: Isotope labeling studies on the formation of acetic acid by a hydrolytic $\beta$-dicarbonyl cleavage mechanism. J. Agric. Food Chem. 2006, 54, 6667-6676. [CrossRef]

103. Davidek, T.; Robert, F.; Devaud, S.; Vera, F.A.; Blank, I. Sugar fragmentation in the Maillard reaction cascade: Formation of short-chain carboxylic acids by a new oxidative $\alpha$-dicarbonyl cleavage pathway. J. Agric. Food Chem. 2006, 54, 6677-6684. [CrossRef] [PubMed]

104. Vhangani, L.N.; Wyk, J.V. Antioxidant activity of Maillard reaction products (MRPs) derived from fructose-lysine and riboselysine model systems. Food Chem. 2013, 137, 92-98. [CrossRef] [PubMed]

105. Kim, W.Y.; Kim, J.M.; Han, S.B.; Lee, S.K.; Kim, N.D.; Park, M.K. Steaming of ginseng at high temperature enhances biological activity. J. Nat. Prod. 2000, 63, 1702-1704. [CrossRef] [PubMed]

106. Kim, S.Y.; Jeong, S.M.; Park, W.P.; Nam, K.C.; Ahn, D.U.; Lee, S.C. Effect of heating conditions of grape seeds on the antioxidant activity of grape seed extracts. Food Chem. 2006, 97, 472-479. [CrossRef] 
107. Bunea, A.; Andjelkovic, M.; Socaciu, C.; Bobis, O.; Neacsu, M.; Verhé, R.; Camp, J.V. Total and individual carotenoids and phenolic acids content in fresh, refrigerated and processed spinach (Spinacia oleracea L.). Food Chem. 2008, 108, 649-656. [CrossRef] [PubMed]

108. Lanzotti, V. The analysis of onion and garlic. J. Chromatogr. A. 2006, 1112, 3-22. [CrossRef] [PubMed]

109. Kim, N.Y.; Park, M.H.; Jang, E.Y.; Lee, J. Volatile distribution in garlic (Allium sativum L.) by solid phase microextraction (SPME) with different processing conditions. Food Sci. Biotechnol. 2011, 20, 775-782. [CrossRef]

110. Molina-Calle, M.; Priego-Capote, F.; de Castro, M.D.L. Headspace-GC-MS volatile profile of black garlic vs fresh garlic: Evolution along fermentation and behavior under heating. LWT Food Sci. Technol. 2017, 80, 98-105. [CrossRef]

111. Lee, B.; Seo, J.D.; Rhee, J.K.; Kim, C.Y. Heated apple juice supplemented with onion has greatly improved nutritional quality and browning index. Food Chem. 2016, 201, 315-319. [CrossRef]

112. Moon, K.M.; Kwon, E.B.; Lee, B.; Kim, C.Y. Recent trends in controlling the enzymatic browning of fruit and vegetable products. Rev. Mol. 2020, 25, 2754. [CrossRef]

113. Kim, S.H.; Jung, E.Y.; Kang, D.H.; Chang, U.J.; Hong, Y.H.; Suh, H.J. Physical stability, antioxidative properties, and photoprotective effects of a functionalized formulation containing black garlic extract. J. Photochem. Photobiol. B Biol. 2012, 117, 104-110. [CrossRef]

114. Borrelli, R.C.; Visconti, A.; Mennella, C.; Anese, M.; Fogliano, V. Chemical characterization and antioxidant properties of coffee melanoidins. J. Agric. Food Chem. 2002, 50, 6527-6533. [CrossRef] [PubMed]

115. Tressl, R.; Wondrak, G.T.; Garbe, L.A.; Krüger, R.P.; Rewicki, D. Pentoses and hexoses as sources of new melanoidin-like Maillard polymers. J. Agric. Food Chem. 1998, 46, 1765-1776. [CrossRef]

116. Rapusas, R.S.; Driscoll, R.H. Kinetics of non-enzymatic browning in onion slices during isothermal heating. J. Food Eng. 1995, 24, 417-429. [CrossRef] 